\title{
UM BALANÇO DOS 30 ANOS DA CONSTITUIÇÃO FEDERAL DE 1998: OS DIREITOS HUMANOS NA JURISPRUDÊNCIA E NOS JUÍZES
}

\author{
AN ANALYSIS OF 30 YEARS OF THE 1988 BRAZILIAN FEDERAL CONSTITUTION: \\ HUMAN RIGHTS IN THE JURISPRUDENCE AND THE JUDGES

\section{UN ANÁLISIS DE LOS 30 AÑOS DE LA CONSTITUCIÓN BRASILEÑA DE 1988: LOS DERECHOS HUMANOS EN LA JURISPRUDENCIA Y EN LOS JUECES}

\section{Ana Claudia Santano'}

Licença CC BY:

Artigo distribuído sob os termos Creative Commons, permite uso e distribuição irrestrita em qualquer meio desde que $o$ autor credite a fonte original.

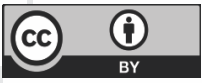

\begin{abstract}
Resumo: Os 30 anos da Constituição de 1988 testemunharam um momento de plena ascensão no reconhecimento dos direitos humanos na ordem constitucional brasileira, a partir do maior rol de direitos fundamentais em seu conteúdo. Contudo, é inegável que há uma crise, que não vem só dessa recognição, mas da própria noção de direitos humanos, comprometendo a frágil consolidação desses valores. Diante disso, por meio de uma breve revisão doutrinária e de análise de alguns dados da jurisprudência do STF e do Tribunal de Justiça do estado do Paraná, este ensaio irá abordar como caminha a abertura constitucional para os direitos humanos internacionais. Verificou-se que ainda há gargalos nesse processo que prejudicam a consolidação desses valores internamente e que, de certa forma, colaboram para a crise apontada. Ao final, traça-se um panorama do que se espera para os próximos 30 anos, principalmente no que se refere à adesão do Brasil a um lus Constitutionale Commune, já presente no âmbito latino-americano.
\end{abstract}

Palavras-chave: Direitos Humanos; Constituição Federal de 1988; Tratados Internacionais: Bloco de Constitucionalidade; Ius Constitutionale Commune.

Abstract: During its thirty years in existence, the 1988 Brazilian Constitution has witnessed a great moment in the recognition of the human rights, starting from the largest list of fundamental rights ever seen. However, it is undeniable that there is a crisis that comes not only from this recognition, but from the very concept of human rights itself, affecting its consolidation. Through a literature review and an analysis of data collected from the jurisprudence systems of the STF [Brazilian Supreme Court] and the TJ-PR [Court of Appeals of the State of Paraná], this essay addresses the route to the constitutional opening for international human rights. It was found that there are still bottlenecks in the processes that can prejudice the consolidation of these values internally, and that may be exacerbating this crisis. At the end, it outlines a panorama of what is expected for the next thirty years, particularly in regard to brazil's participation in the lus Constitutionale Commune, which is already present in the Latin American context.

1 Professora do Programa de Mestrado e Doutorado em Direitos Fundamentais e Democracia do Centro Universitário Autônomo do Brasil UniBrasil. Pós-doutora em Direito Público Econômico pela Pontifícia Universidade Católica do Paraná. Doutora e mestre em Ciências Jurídicas e Políticas pela Universidad de Salamanca, Espanha. Curitiba, Paraná, Brasil. E-mail: anaclaudiasantano@yahoo.com.br. 


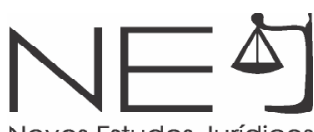

Keywords: Human Rights; 1988 Federal Constitution; International Treaties; Constitutional Block; Ius Constitutionale Commune.

Resumen: Los 30 años de la Constitución de 1988 fueron testigos de un momento de mucha ascensión en el reconocimiento de los derechos humanos en el orden constitucional brasileño, a partir de más largo listado de derechos fundamentales jamás visto. Sin embargo, es innegable que hay una crisis que no viene sólo de dicho reconocimiento, sino también de la propia noción de derechos humanos, lo que compromete la consolidación de dichos valores. Ante eso, por medio de una breve revisión doctrinal y del análisis de algunos datos extraídos del sistema de jurisprudencia del STF y del TJ-PR, este ensayo expondrá cómo está el proceso de apertura constitucional para los derechos humanos internacionales. Se verificó que todavía hay muchos cuellos de botella en este camino que perjudican la concreción de estos valores internamente y que, de cierta forma, colaboran para la crisis señalada. Al final, se expone un panorama de lo que se espera en los próximos 30 años, principalmente en lo que se refiere a la adhesión de Brasil a un lus Constitutionale Commune, ya presente en el ámbito latinoamericano.

Palabras clave: Derechos Humanos; Constitución Federal de 1988; Tratados Internacionales; Bloque de Constitucionalidad; Ius Constitutionale Commune.

\section{INTRODUÇÃO}

O projeto constitucional de 1988 foi muito desejado. E não era para menos. Havia, de fato, toda uma mobilização popular que vinha desde o movimento das Diretas Já, clamando por uma nova ordem constitucional que rompesse definitivamente as amarras do regime ditatorial, ${ }^{2}$ resultando, assim, na elaboração da Constituição Federal de 1988, também conhecida como "Constituição Cidadã".3

Foi nesse momento que se viu no Brasil uma intensa inclusão de direitos e garantias fundamentais. Ainda que muitos deles já estivessem presentes na história constitucional brasileira, o fato é que, em muitas ocasiões, a sua mera previsão legal camuflava a realidade, como ocorreu na Constituição de 1824 e os direitos civis e políticos - algo que caracterizada o momento devido à era das revoluções, mas que mascarava a existência da escravidão e a do voto censitário -; na Constituição de 1937, que continha um conjunto formal de direitos, a fim de disfarçar a ditadura do Estado Novo; e na Constituição de 1967 e na Emenda $n^{\circ} 1$ de 1969, que mantiveram o perfil apenas formal dos direitos, mas que se sujeitavam a outros decorrentes do regime militar. ${ }^{4}$

Assim, a opção do constituinte de 1988 foi pela introdução da mais extensa e abrangente lista de direitos de distintas espécies, como os civis; os políticos; os econômicos; os sociais; os culturais; os ambientais, dentre outros. Além disso, este bloco de direitos não é exaustivo, uma vez que há uma abertura da Constituição para a inclusão de outros decorrentes do(s) (i) regime; (ii) princípios

2 SALGADO, Eneida Desiree. Constituição e democracia - tijolo por tijolo em um desenho (quase) lógico: vinte anos de construção do projeto democrático brasileiro. Belo Horizonte: Fórum, 2007. p. 201.

3 Alcunha dada por Ulisses Guimarães no momento da promulgação do texto, em 5 de outubro de 1988, sendo amplamente repetido por toda a doutrina. Nesse sentido, cf. CHUEIRI, Vera Karam de. Fundamentos do Direito Constitucional. Curitiba: IESDE, 2009. p. 33. 
da Carta; (iii) tratados internacionais de direitos humanos ${ }^{5}$ celebrados pelo Brasil, tal como consta no art. 5, §2०. ${ }^{6}$ No entanto, os 30 anos da Constituição de 1988 testemunharam um momento de plena ascensão no reconhecimento dos direitos humanos na ordem constitucional brasileira, mas também uma crise, que não vem só dessa recognição, mas da própria noção de direitos humanos, comprometendo a frágil consolidação desses valores. Parece que o Brasil, a despeito de ter adicionado tantos direitos humanos ao seu principal documento, ainda convive com um hiato existente entre a lei e a realidade, o que sugere que os aplicadores do direito ainda possam ser resistentes a esta abertura constitucional a este rol de direitos humanos.

Diante disso, e considerando que a Declaração Universal dos Direitos Humanos e a Declaração Americana dos Direitos e Deveres do Homem também completam 70 anos, por meio de uma breve revisão doutrinária e de análise de dados da jurisprudência do STF e do Tribunal de Justiça do estado do Paraná, este comentário irá abordar como caminha a abertura constitucional para os direitos humanos internacionais, tendo em vista que textos progressistas como o da Constituição de 1988 também exigem mentalidades progressistas que os apliquem no mundo real. Após, buscam-se algumas razões que possam ao menos tentar explicar esta distância entre as decisões dos juízes e o seu reconhecimento dos direitos humanos constantes na legislação nacional e internacional. Ao final, traça-se um panorama do que se espera para os próximos 30 anos, considerando que ainda há um longo caminho a ser percorrido.

\section{UM ESCLARECIMENTO TERMINOLÓGICO NECESSÁRIO SOBRE DIREITOS HUMANOS E FUNDAMENTAIS}

Não é difícil encontrar algum trabalho escrito em que é possível verificar o uso dos direitos humanos e direitos fundamentais como sinônimos. Além dessas expressões, há outras, como "direitos do homem", "direitos subjetivos públicos", "liberdades públicas", ou até mesmo "direitos individuais", "liberdades fundamentais" e "direitos humanos fundamentais".

$5 \quad$ Apenas a título de explanação, neste trabalho a expressão "direitos humanos" terá sentido distinto quando escrito com letras minúsculas e maiúsculas. Quando minúsculas, referir-se-á ao que André de Carvalho Ramos menciona como "um conjunto de direitos considerado indispensável para uma vida humana pautada na liberdade, igualdade e dignidade", ou seja, aqueles indispensáveis à vida digna (cf. RAMOS, André de Carvalho de. Curso de Direitos Humanos. 4. ed., 2017. p. 29). Por outro lado, quando escrito com letras maiúsculas, fará alusão ao ramo do Direito.

6 Art. 5, $\S 2^{\circ}$ : "Os direitos e garantias expressos nesta Constituição não excluem outros decorrentes do regime e dos princípios por ela adotados, ou dos tratados internacionais em que a República Federativa do Brasil seja parte". Esta abertura já constava em outras Cartas constitucionais, como a de 1891 ("Art. 78 - A especificação das garantias e direitos expressos na Constituição não exclui outras garantias e direitos não enumerados, mas resultantes da forma de governo que ela estabelece e dos princípios que consigna"), mas é a primeira vez que a abertura da Constituição se baseia também nos tratados internacionais de Direitos Humanos nos que o Brasil faz parte. 
Isso vem, também77, devido às diversas terminologias adotadas pelas constituições brasileiras e que, de uma forma ou de outra, transmite-se - equivocadamente - a mensagem de que haveria uma coincidência de sentidos. A Constituição de 1824 utilizava a expressão "Garantias dos Direitos Civis e Políticos dos Cidadãos Brasileiros". A Constituição de 1891, a partir das Declarações de Direitos dos séculos XVII e XVIII, usava apenas a expressão "Declaração de Direitos" (epígrafe da Secção II do Título IV - Dos cidadãos brasileiros). Foi somente na Constituição de 1934 que pela primeira vez se adotou a expressão "Direitos e Garantias Individuais", que seria mantida nas Constituições de 1946 e 1967-1969, compondo o Título da Declaração de Direitos. Já a Constituição de 1988 inovou por completo ao nominar como Direitos e Garantias Fundamentais, como forma de abranger as diversas espécies de direitos, que, segundo a terminologia e a classificação já consagradas no direito constitucional positivo brasileiro vigente, são os direitos (e deveres) individuais e coletivos; os direitos sociais (englobando os direitos dos trabalhadores); os direitos de nacionalidade e os direitos políticos (incluindo o estatuto constitucional dos partidos políticos e a liberdade de associação partidária). Desse modo, optou-se por considerar os direitos e as garantias fundamentais como gênero e as demais categorias como espécies, em uma clara aderência do direito constitucional brasileiro à tendência dominante no direito comparado, como era o caso da Lei Fundamental da Alemanha, de 1949. ${ }^{8}$

Dessa forma, a fim de precisar melhor o objeto desse breve estudo, entende-se aqui que somente os direitos humanos são mais abrangentes que os direitos fundamentais, sendo todas as demais expressões algo mais limitado. Isso porque os direitos humanos, ainda que não sejam antagônicos aos direitos fundamentais, refletem direitos positivados na esfera internacional, enquanto os direitos fundamentais são compostos por direitos humanos que foram integrados a uma ordem jurídica constitucional de um Estado. Reconhece-se que essa "diferenciação" não é tão clara, ainda mais porque não se pode afirmar que os direitos humanos não são exigíveis internamente em um país ${ }^{9}$ e nem que não possam ser objeto de cobrança judicial ${ }^{10}$, acolhendo-se, aqui, as observações de André de Carvalho Ramos. ${ }^{11}$ No entanto, ainda parece ser um esclarecimento, ao menos didático, que pode auxiliar na compreensão de temas vinculados. Assim, aplicar-se-á nesse ensaio o termo "direitos fundamentais" para os direitos (geralmente atribuídos à pessoa humana) reconhecidos e positivados

7 A mesma situação também se verifica no Direito Internacional. A Declaração Americana dos Direitos e Deveres do Homem de 1948 traz em seu preâmbulo "direitos do homem" e "direitos essenciais do homem". A Declaração Universal de Direitos Humanos estabelece os "direitos do homem" e os "direitos fundamentais do homem". A Carta das Nações Unidas emprega a expressão "direitos humanos" e "liberdades fundamentais".

8 SARLET, Ingo Wolfgang; MARINONI, Luiz Guilherme; MITIDIERO, Daniel. Curso de Direito Constitucional. São Paulo: Revista dos Tribunais, 2012. p. 248.

9 Isso é confirmado no Brasil, por exemplo, com o art. $5^{\circ}, 3^{\circ}$ da Constituição Federal de 1988.

10 A exemplo do Tribunal Europeu de Direitos Humanos e da Corte Interamericana de Direitos Humanos. Ainda, cf. ATIQUE, Henry; NEME, Eliane Franco. O processo de internacionalização como instrumento de efetivação dos direitos humanos: o sistema europeu e o sistema americano. Novos Estudos Jurídicos. v. 13, n. 1, p. 95-106, jan./jun. 2008.

11 Cf. RAMOS, André de Carvalho de. Curso de Direitos Humanos. 4. ed., 2017. p. 52-53. 
no direito constitucional positivo de determinado Estado (utilizando-se as lições de Canotilho ${ }^{12}$ ), e "direitos humanos" para se referir aos constantes nos documentos de direito internacional, considerando o ser humano como tal, independentemente de sua vinculação com determinada ordem constitucional, tendo, portanto, validade universal para todos os povos e em todos os lugares, o que ressalta o seu perfil supranacional (internacional) e universal. ${ }^{13}$

Dessa forma, a exposição se centrará não nos direitos fundamentais já consolidados na Constituição de 1988 (tidos aqui como direitos humanos fundamentais, por serem direitos humanos já plenamente inseridos na ordem constitucional brasileira $\left.{ }^{14}\right)$, mas sim nos demais direitos humanos constantes nos documentos internacionais e decisões das cortes que compõem o sistema internacional de proteção dos direitos humanos, e na maneira como ocorre a sua realização e interpretação no plano interno. Afinal: a Constituição de 1988, com a sua abertura para os direitos oriundos de tratados internacionais de direitos humanos, conseguiu avanços nesses 30 anos?

\section{UMA PERSPECTIVA HISTÓRICA DOS DIREITOS HUMANOS E FUNDAMENTAIS}

Segundo a relação do indivíduo com o Estado (teoria do "status" desenvolvida por Georg Jellinek), há quatro situações do indivíduo diante do Estado. Na primeira, há uma submissão (status subjectionis ou passivo), em que os indivíduos se subordinam ao Estado, originando deveres de ambos para o alcance do bem comum. A segunda situação é a negativa, quando o Estado se abstém diante dos direitos dos indivíduos, assegurando o seu exercício na vida privada. Já a terceira situação é a positiva, justamente oposta da anterior, que é quando o Estado é chamado a agir para garantir os direitos dos indivíduos. A classificação termina com a quarta situação, a ativa, que consiste no conjunto de faculdades e prerrogativas que o cidadão tem para participar da formação da vontade do Estado, tendo, para isso, os direitos políticos e o de acessar cargos em órgãos públicos (aqui não necessariamente cargos eletivos, mas públicos em geral). ${ }^{15}$ Anos mais tarde, a ampliação da ideia de uma posição ativa diante do Estado foi defendida por Häberle, transformando esse "status" não somente em "activus", mas também em "processualis", ou seja, que o indivíduo também tivesse o direito de participar no procedimento da tomada de decisão por parte do Poder Público, não se limitando a se manifestar, mas também a influenciar e ter o seu posicionamento levado em consideração na adoção de uma decisão, incluindo aqui o resultado dos trabalhos de Tribunais Constitucionais. ${ }^{16}$

\footnotetext{
12 CANOTILHO, José Joaquim Gomes. Direito Constitucional. 6. ed. rev. Coimbra: Almedina, 1993. p. 497.

13 Cf. MIRANDA, Jorge. Manual de Direito Constitucional. Tomo IV. 4. ed. rev. atual. Coimbra: Coimbra Editora, 2008. p. 15-16.

14 André de Carvalho Ramos entende que se trata de uma nova nomenclatura que demonstra que a diferenciação entre direitos humanos como direitos do plano internacional e direitos fundamentais como oriundos da ordem interna perde sua importância, ainda mais se se considera o processo de aproximação e mútua relação entre o Direito Internacional e o Direito interno na temática dos Direitos Humanos (RAMOS, André de Carvalho de. Curso de Direitos Humanos. 4. ed., 2017. p. 53).

15 JELLINEK, Georg. System der Subjektiven Öffentlichen Rechte. Freiburg: Mohr, 1892. p. 129-140.

16 HÄBERLE, Peter. Hermenêutica constitucional: a sociedade aberta de intérpretes da Constituição: contribuição para a interpretação pluralista e procedimental da Constituição. Tradução de Gilmar Ferreira Mendes. Porto Alegre: Sergio Antônio Fabris Editor, 1997. p. 19-23.
} 
Outra classificação muito reconhecida é a clássica teoria das gerações de Karel Vasak. Esta teoria é construída sobre a expressão mais representativa da Revolução Francesa, liberté, egalité et fraternité, sendo que a primeira geração são os direitos vinculados à liberdade; a segunda que reporta a direitos de igualdade; e a terceira que se refere aos direitos conectados com a solidariedade social. ${ }^{17} \mathrm{~A}$ classificação em gerações sofre forte crítica doutrinária, como a de Cançado Trindade, que lista ao menos 4 (quatro) razões para não adotá-la: (i) transmite uma falsa ideia de substituição de uma geração por outra, já que os direitos se complementam; (ii) faz parecer que uma geração é mais antiga do que a outra, o que não é verdadeiro necessariamente, como ocorre no caso dos direitos sociais e sua consolidação junto à OIT, em 1919, para somente depois, em 1948, ser aprovada a Declaração Universal dos Direitos Humanos, com os direitos civis e políticos; (iii) apresenta os direitos de forma fragmentada, violando a indivisibilidade que os permeia; (iv) esta classificação pode afetar as novas interpretações dos Direitos Humanos em seu conteúdo, devido ao seu encaixe pouco exato em uma das gerações, já que o direito à vida, por exemplo, pode ser tanto de defesa ( $1^{\circ}$ geração) quanto de prestação positiva estatal ( $2^{\circ}$ geração).$^{18}$

Vale ressaltar que a doutrina mais moderna já abandonou a terminologia "gerações" e utiliza o termo "dimensões", justamente devido a essas críticas. ${ }^{19}$ Diante disso, é inevitável não perceber que há o fator cronológico incidindo sobre essas classificações, que foram aprimorando a tipologia desses direitos. Como exemplo, a primeira dimensão de direitos que, como já dito, é composta pelos direitos civis, que, junto com os direitos políticos, compõem o regramento da esfera do indivíduo e da estatal, delimitando o espaço de liberdade dos sujeitos diante da organização do Estado e de seu poder. São os primeiros direitos individuais que se delinearam, acompanhando praticamente todas as revoluções históricas que visavam restringir o poder da monarquia absolutista em um momento cuja atuação do Estado era confundida com a do próprio monarca. É nesse ponto que é possível narrar, ainda que brevemente, a trajetória histórica dos direitos humanos.

Para entender o caminho realizado pelos revolucionários na direção da limitação do alcance estatal na esfera do indivíduo, necessário se faz retornar ao que Benjamin Constant tratou em seu artigo sobre a "liberdade dos antigos" e a "liberdade dos modernos". ${ }^{20}$ Segundo a leitura feita pelo autor, os antigos viam a liberdade como uma possibilidade de participar da vida social na cidade, desconhecendo a autonomia privada, algo que não ocorria com os modernos, os iluministas do

17 VASAK, Karel. A 30-Year struggle: the sustained efforts to give force of law to the Universal Declaration of Human Rights. The Unesco Courier. Paris: Unesco, 1977. p. 29-32. Disponível em: http://unesdoc.unesco.org/images/0007/000748/074816eo.pdf\#nameddest=48063. Acesso em: 14 nov. 2017

18 Cf. TRINDADE, Antônio Augusto Cançado. Cançado Trindade Questiona a Tese de "Gerações de Direitos Humanos" de Norberto Bobbio. Disponível em: http://www.dhnet.org.br/direitos/militantes/ cancadotrindade/cancado_bob.htm. Acesso em: 14 jun. 2018. Devido a essas críticas, a doutrina sugere a utilização do termo "dimensões" no lugar de "gerações".

19 Nesse sentido, cf. um dos primeiros autores a assim se posicionar: BONAVIDES, Paulo. Curso de Direito Constitucional. 26. ed. São Paulo: Malheiros, 2010. p. 571-572. Já na doutrina estrangeira mais clássica, cf. RIEDEL, Eibe. Menschenrechte der Dritten. In: Europäische Grundrechte-Zeitung, 9-21, 1989.

20 CONSTANT, Benjamin. The liberty of ancients compared with that of moderns. Disponivel em: http://ff-oll.s3.amazonaws.com/titles/2251/ Constant_Liberty1521_EBk_v6.0.pdf. Acesso em: 14 jun. 2018. 
século XVIII e pensadores do século XIX, que entendiam a liberdade como a oportunidade de viver sem amarras na vida privada, não importando se há ou não participação política. Esse debate foi o propulsor que desencadeou a discussão sobre a limitação do poder do Estado, culminando, assim, no seu período pré-constitucional. ${ }^{21}$

O processo de limitação do poder estatal iniciou-se com a Magna Charta Libertatum, também conhecida como Magna Carta (séc. XIII), sendo o primeiro documento que tem como objetivo restringir o poder do monarca absolutista. Nesse sentido, é devido a essa primeira tentativa de limitação institucional dos poderes do rei que a democracia moderna surge em seu embrião, que, embora distante de uma democracia grega baseada em cidadãos ativos nas mais variadas funções públicas, ensaia o conceito de soberania popular, ainda que passiva ou meramente formal. ${ }^{22}$ Outros direitos que também se fundamentavam na liberdade foram incluídos nela, como o que depois se conheceria como garantias processuais, como o devido processo legal, bem como o direito de propriedade, como outra ordem da tutela da liberdade individual.

O movimento de uma limitação cada vez maior do Estado se intensificou na Revolução Gloriosa e continuou com a Petition of Rights, em 1628, já com a presença de um Parlamento, o inglês, o que denotava a democracia representativa como o modelo então adotado. Uma maior conformação desse parlamento veio com a Bill of Rights, em 1689, reduzindo-se definitivamente o poder autocrático dos reis ingleses. ${ }^{23}$ Trata-se de um documento não muito extenso, em que se determinou a institucionalização da separação de poderes no Estado, o direito de petição e o estabelecimento de liberdades como a de expressão e política, além da tolerância (mas não liberdade) religiosa.

A tutela da liberdade individual também ganhou um reforço nesse período, pois em 1679 foi elaborado o Habeas Corpus Act, que se opunha à prisão ilegal, abusiva ou arbitrária. Este documento foi tão importante que, até os dias de hoje, o instituto do habeas corpus goza de muito prestígio no rol de Direitos Humanos e Fundamentais.

Por outro lado, cabe destacar que havia um processo revolucionário em outros países também. A Revolução Estadunidense é uma delas, que teve como ponto principal a defesa das liberdades públicas contra o absolutismo do rei, culminando na declaração de independência dos Estados Unidos (1776). Nela, a defesa das liberdades individuais se fazia presente, juntamente com a submissão dos poderes governamentais ao consentimento popular, que se fundamenta em uma

21 No entanto, essa separação entre liberdade pública e liberdade privada não se sustentou com o tempo, já que as liberdades individuais sem participação política do povo no governo somente respondem ao que Konder Comparato chama de "dominação oligárquica dos mais ricos" (Cf. COMPARATO, Fábio Konder. A afirmação histórica dos Direitos Humanos. 10. ed. São Paulo: Saraiva, 2016. p. 78-79).

22 COMPARATO, Fábio Konder. A afirmação histórica dos Direitos Humanos. 10. ed. São Paulo: Saraiva, 2016. p. 92-93.

23 Até os dias de hoje, devido ao seu caráter de lei fundamental, a Bill of Rights é um dos textos constitucionais mais importantes do Reino Unido, em uma época que "constituição" e "lei fundamental" eram complementares (Cf. COMPARATO, Fábio Konder. A afirmação histórica dos Direitos Humanos. 10. ed. São Paulo: Saraiva, 2016. p. 106). 


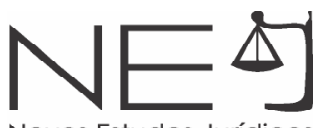

ideia de soberania popular, até então inédita, ou seja, "uma nação só está legitimada a autoafirmar a sua independência, porque o povo que a constitui detém o poder político supremo". ${ }^{24}$ Está aqui o termo inicial da democracia moderna.

Esse novo paradigma de soberania popular se confirmou com a Declaração do Bom Povo da Virgínia (1776), a partir do reconhecimento dos "direitos inatos" de toda pessoa humana, os quais por sua vez não podem ser alienados ou suprimidos por uma decisão política, bem como o atesta o princípio de que todo poder emana do povo, sendo os governantes a esse subordinado. Além disso, havia a previsão do direito do povo substituir os governantes ou mesmo mudar a forma de governo, caso aquela aplicada não fosse capaz de realizar os fins da sociedade. ${ }^{25}$ Nessa linha, o documento também proclamava que todo ser humano é titular de direitos, como o direito à vida, à liberdade, à busca da felicidade, trazendo também o direito de resistência. Nota-se, aqui, uma fundamentação jusnaturalista para esses direitos. Já alguns anos mais tarde, promulgou-se a Constituição Estadunidense, a primeira do mundo (1787), coroando o processo do constitucionalismo liberal. ${ }^{26}$

Outra revolução que se avizinhava era a francesa, também de notória importância histórica. O descontentamento generalizado face à ineficiência, à incapacidade de gestão e ao custo do Estado francês eclodiu na autoproclamação de uma Assembleia Nacional Constituinte, em 1789, na qual se adotou a Declaração Francesa dos Direitos do Homem e do Cidadão, que seria parte da própria Constituição Francesa de 1791, consagrando até hoje a igualdade e a liberdade como direitos inatos a todos os indivíduos. Aqui, pode-se dizer que o acontecimento foi inteiramente político, já que objetivou uma renovação completa das estruturas sociopolíticas e nas relações de poder que as compõem. ${ }^{27}$ Para tanto, reconheceram a soberania popular, abolindo as diferenças de voto entre os cidadãos e o sistema de governo representativo. Ainda, para universalizar os princípios da liberdade, igualdade e fraternidade, pregou-se um Estado laico, bem como diversas garantias processuais, como o princípio da reserva legal, da anterioridade e do estado de inocência, propriedade, segurança e resistência à opressão, além de outros, no sentido de conservar os direitos naturais e imprescindíveis das pessoas.

O que se seguiu a partir de então foi a crescente reafirmação de direitos, primeiro dentro do contexto da própria confirmação dos Direitos Humanos, logo como Direitos Fundamentais. O advento dos direitos sociais com a Constituição Mexicana de 1917, acompanhada da Constituição de Weimar de 1919 somaram-se a esse conjunto de direitos que se complementam na direção de sua

24 COMPARATO, Fábio Konder. A afirmação histórica dos Direitos Humanos. 10. ed. São Paulo: Saraiva, 2016. p. 118.

25 COMPARATO, Fábio Konder. A afirmação histórica dos Direitos Humanos. 10. ed. São Paulo: Saraiva, 2016. p. 127-128.

26 Somente a título de curiosidade, essa Constituição não possuía um rol de direitos, algo que foi feito somente com as 10 (dez) primeiras emendas posteriormente. Temia-se introduzir direitos humanos em um diploma que tinha outros objetivos, como a organização da esfera federal (Cf. RAMOS, André de Carvalho. Curso de direitos humanos. 4. ed. São Paulo: Saraiva, 2017. p. 44). 
garantia e proteção. A história constitucional brasileira em muito se identifica com essa trajetória, levando, eventualmente, mais tempo para o reconhecimento de alguns direitos devido à sua própria realidade. No entanto, mesmo com essa diferença temporal, o constitucionalismo brasileiro se consolida em 1988, com - repita-se - o reconhecimento do maior rol de direitos fundamentais já visto. Porém, essa força não se vê com tanta nitidez com relação aos direitos humanos.

\section{A RECEPÇÃO E A INTERPRETAÇÃO DOS TRATADOS INTERNACIONAIS DE DIREITOS HUMANOS NO ORDENAMENTO JURÍDICO BRASILEIRO}

A ordem constitucional de 1988 se preocupou muito em adotar medidas que pudessem incorporar os instrumentos internacionais voltados à proteção dos direitos humanos, e foi a partir da promulgação do texto constitucional que muitos tratados importantes foram ratificados. De fato, entre 1988 e 2004 houve uma série de ratificações por parte do Brasil em tratados vinculados à temática de Direitos Humanos, transferindo a principiologia desses instrumentos internacionais à realidade constitucional. ${ }^{28}$ É nessa esteira que vem o art. $5^{\circ}, \S 2^{\circ}$ da Constituição Federal, quando inclui os tratados internacionais de Direitos Humanos no rol de direitos e garantias, conferindo hierarquia constitucional a esses instrumentos internacionais, formando o que se denomina de bloco de constitucionalidade. ${ }^{29}$

Contudo, o debate sobre o encaixe da ordem jurídica interna e internacional, além de não ser exclusivamente brasileiro, impõe aos jusinternacionalistas um grande desafio, uma vez que as normas protetivas de direitos humanos possuem natureza jus cogens ${ }^{30}$, tendo como base axiológica a dignidade da pessoa humana, o que faz com que o Direito Internacional deva ser reconhecido a todos

PIOVESAN, Flávia. Direitos humanos e o direito constitucional internacional. São Paulo: Saraiva, 2006. p. 260. Desde 1988, foram ratificados os seguintes tratados e declarações: Declarações de Direitos Humanos aprovadas pelo Brasil: 1. Declaração Universal dos Direitos Humanos (1948); 2. Declaração sobre o Direito ao Desenvolvimento (1986); 3. Declaração e Programa de Ação de Viena (1993); 4. Declaração de Pequim adotada pela quarta conferência sobre as mulheres: ação para igualdade, desenvolvimento e paz (1995); 5 . Declaração Americana dos Direitos e Deveres do Homem (1948); 6. Convenção para Prevenção e a Repressão do crime de genocídio (1948); 7. Convenção Relativa ao Estatuto dos Refugiados (1951); 8. Protocolo sobre o Estatuto dos Refugiados (1966); 9. Pacto Internacional sobre Direitos Civis e Políticos (1966); 10. Protocolo Facultativo relativo ao Pacto Internacional sobre Direitos Civis e Políticos (1966); 11. Pacto Internacional dos Direitos Econômicos, Sociais e Culturais (1966); 12. Convenção Internacional sobre Eliminação de todas as formas de Discriminação Racial (1965); 13. Convenção Internacional sobre Eliminação de todas as formas de Discriminação contra a Mulher (1979); 14. Protocolo Facultativo à Convenção Internacional sobre Eliminação de todas as formas de Discriminação contra a Mulher (1999); 15. Convenção contra a tortura e outros Tratamentos ou Penas cruéis, desumanas ou degradantes (1984); 16. Convenção sobre os Direitos das Crianças (1989); 17. Protocolo Facultativo à Convenção sobre os Direitos da Criança referente à venda de criança, à prostituição infantil e à pornografia infantil (2000); 18. Protocolo Facultativo à Convenção sobre os Direitos da Criança relativo ao envolvimento de crianças em conflitos armados (2000); 19. Convenção das Nações Unidas contra corrupção (2000) - Convenção de Mérida; 20. Convenção Americana sobre Direitos Humanos (1969) - Pacto de San José da Costa Rica; 21. Estatuto da Corte Interamericana de Direitos Humanos (1979); 22. Protocolo Adicional à Convenção Americana sobre Direitos Humanos em matéria de direitos econômicos, sociais e culturais (1988) - Protocolo de San Salvador; 23. Protocolo à Convenção Americana sobre Direitos Humanos referentes à abolição da pena de morte (1990); 24. Convenção Interamericana para prevenir e punir a Tortura (1985); 25. Convenção Interamericana para prevenir, punir e erradicar a violência contra a Mulher (1994) Convenção de Belém do Pará; 26. Convenção Interamericana sobre Tráfico Internacional de Menores (1994); 27. Convenção Interamericana para a eliminação de todas as formas de discriminação contra as pessoas portadoras de deficiência (1999). (Lista extraída do Observatório de Relações Internacionais, do Núcleo de Estudos sobre Cooperação e Conflitos Internacionais da Universidade Federal de Ouro Preto (NECCINT) https://neccint.wordpress.com/legislacao-internaciona/. Acesso em: 22 jun. 2018).

29 Cf. CARVALHO, Feliciano de. Teoria do bloco de constitucionalidade. Anais do XXIII Congresso Nacional do CONPEDI/UFPB. Florianópolis, 2015, p. 418-444; SANTIAGO, Nestor Araruna; MARTINS, Eduardo Almendra. O garantismo e os precedentes da Corte Interamericana de Direitos Humanos: efeito vinculante aos Estados sob sua jurisdição. Revista Novos Estudos Jurídicos - Eletrônica, Vol. 21 - n. 2 - mai-ago 2016. p. 576 e ss.

30 Por força do art. 53 da Convenção de Viena de 1969: "É nulo um tratado que, no momento de sua conclusão, conflite com uma norma imperativa de Direito Internacional geral. Para os fins da presente Convenção, uma norma imperativa de Direito Internacional geral é uma norma aceita e reconhecida pela comunidade internacional dos Estados como um todo, como norma da qual nenhuma derrogação é permitida e que só pode ser modificada por norma ulterior de Direito Internacional geral da mesma natureza". 
os seres humanos, em qualquer parte do mundo e em qualquer época, atendendo à universalidade desses direitos. ${ }^{31}$ Nesse sentido, ainda que seja uma realidade a intensa comunicação entre o Direito Internacional e o Direito Constitucional dos Estados, podendo, inclusive, superar as visões monista e dualista32 devido à prevalência da norma mais favorável ao indivíduo ${ }^{33}$, quer nacional, quer internacional ${ }^{34}$, o fato é que, no Brasil, a questão não vem sendo tratada com tanta objetividade. Pelo menos, não ao longo dos 30 anos da Constituição.

Contudo, mesmo nessa direção, permanecia entre os tratados e a realidade brasileira uma distância de internalização prática do conteúdo e das disposições. Há autores que afirmam a existência de um descompasso entre os compromissos assumidos pelo Brasil no plano internacional e a sua aplicabilidade. ${ }^{35} \mathrm{E}$ isso, de certa forma, é devido à recepção tanto pelo Poder Legislativo como pelo Poder Judiciário dos tratados internacionais de direitos humanos. A análise sobre a receptividade dos tratados de direitos humanos deve ser feita conjugando a atuação do Poder Legislativo e do Poder Judiciário. No que tange ao Poder Legislativo - mais especificamente ao constituinte -, a opção foi feita por meio do art. $5^{\circ}, \S 2^{\circ}$, deixando em evidência que o bloco de constitucionalidade incluía tais documentos. Nesse sentido, muitos autores defendiam o seu status constitucional, seguindo uma estrita interpretação do texto constitucional. ${ }^{36}$

Contudo, a interpretação da posição hierárquica dos tratados de direitos humanos pelo STF não correspondia a isso, levando a Corte a definir o caráter infraconstitucional desses diplomas legais, ${ }^{37}$ o que gerou muitos debates e críticas, justamente porque afetava a eficácia dos direitos humanos na ordem interna brasileira. ${ }^{38}$ Ocorre que, anos mais tarde, foi aprovada a EC $n^{\circ} 45 / 2004$, que acrescentou o $\$ 3^{\circ}$ ao art. $5^{\circ}$ do texto constitucional, estabelecendo que os tratados internacionais de Direitos Humanos somente teriam status constitucional se fossem internalizados por meio de um

31 GUERRA, Sidney. Controle de convencionalidade. Revista Jurídica. vol. 01, n. 46, Curitiba, 2017. p. 4

32 Devido aos limites desse trabalho, não se abordará o "embate" entre monistas e dualistas. Para tanto, sugere-se a leitura de: AVELAR, Daniel PRONER, Carol. A natureza jurídica dos tratados internacionais de direitos humanos e sua harmonização e aplicabilidade no ordenamento jurídico brasileiro. Revista de Direitos Fundamentais e Democracia, Curitiba, v. 10, n. 10, p. 38-87, jul./dez. 2011.

33 Sobre o princípio pro homine, cf. LORA ALARCÓN, Pietro de Jesús. Constituição e Direito Intergentium: a ductibilidade pro homine e o possível ius commune para os desafios jurídicos contemporâneos. In: PAGLIARINI, Alexandre Coutinho; DIMOULIS, Dimitri (Coord.). Direito constitucional e internacional dos direitos humanos. Belo Horizonte: Fórum, 2012. p. 49-72.

34 Segundo Cançado Trindade, "no presente domínio de proteção, não mais há pretensão de primazia do direito internacional ou do direito interno, como ocorria na polêmica clássica e superada entre monistas e dualistas. No presente contexto, a primazia é da norma mais favorável às vítimas, que melhor as proteja, seja ela norma de direito internacional ou de direito interno." (Cf. TRINDADE, Antônio Augusto Cançado. Tratado de direito internacional dos direitos humanos. Porto Alegre: Sérgio Antônio Fabris Editor, 1997. v. 1, p. 434).

35 Nesse sentido, cf. FACHIN, Luiz Edson. Notas para um ensaio sobre a posição jurídica dos tratados internacionais de direitos humanos no Brasil após a reforma constitucional. In: PRONER, Carol; CORREAS, Óscar (Coord.). Teoria crítica dos direitos humanos. Belo Horizonte: Fórum, 2011. p. 157.

36 Nesse sentido, cf. a posição favorável ao status constitucional dos tratados internacionais de direitos humanos nesse período de VELLOSO, Carlos Mario da Silva. Os tratados na jurisprudência do Supremo Tribunal Federal. Revista de informação legislativa, v. 41, n. 162, abr./jun. 2004. p. 39; bem como o seu voto no HC n. 82.424-RS, STF. Assim ele se pronunciava à época: "Nesse caso, no caso de tratar-se de direito e garantia decorrente de Tratado firmado pelo Brasil, a incorporação desse direito e garantia, ao direito interno, dá-se com status constitucional, assim com primazia sobre o direito comum. É o que deflui, claramente, do disposto no mencionado $\S 2^{\circ}$ do art. $5^{\circ}$ da Constituição da República. O Supremo Tribunal Federal, todavia, não acolheu essa tese [citando, aqui, os precedentes de então: ADI 1.480-MC/DF, Rel. Min. Celso de Mello, DJ de 18.05.01 e HC 76.561/SP, Rel. Min. Nelson Jobim, Plenário, 27.05.98, DJ de 02.02.01]".

37 STF, HC 72.131. Rel. Min. Moreira Alves. Julg. 23.11.1995. Caso que envolve a prisão do depositário infiel.

38 MEYER-PFLUG, Samantha Ribeiro. A internacionalização do Direito Constitucional brasileiro. In: PAGLIARINI, Alexandre Coutinho; DIMOULIS, Dimitri (Coord.). Direito constitucional e internacional dos direitos humanos. Belo Horizonte: Fórum, 2012. p. 284. 
trâmite de emenda constitucional, ou seja, a sua aprovação em cada Casa do Congresso Nacional, em dois turnos, por três quintos dos votos dos respectivos membros. Isso, para alguns, seria uma forma de sanar a problemática da internalização dos tratados internacionais de Direitos Humanos, dando unicidade e alçando um novo patamar hierárquico a estes instrumentos. ${ }^{39}$ Porém, o debate somente se intensificou justamente porque limitou a efetividade dos tratados de direitos humanos no plano interno. Novamente a posição hierárquica dos tratados internacionais de direitos humanos foi posta em pauta no STF. ${ }^{40}$ Em outro julgado ${ }^{41}$, o Min. Sepúlveda Pertence, no momento de fundamentar o seu voto, sustentou que se deveria aceitar a força supralegal aos tratados de direitos humanos, de modo a dar aplicação imediata às suas normas, inclusive contra lei ordinária interna sempre que isso não fira a Constituição. Assim, os instrumentos internacionais de direitos humanos ficariam acima das leis e abaixo da Constituição, tese esta que somente após a sua aposentadoria ganharia força. ${ }^{42}$

O certo é que, na época, havia uma variedade de posições sobre a hierarquia dos tratados de direitos humanos que só foram revistas após a EC 45/2004. As de maior destaque eram: (i) natureza supraconstitucional, considerando a sua origem internacional; (ii) natureza constitucional, com forte apoio doutrinário; (iii) natureza equiparada à lei ordinária, entendimento do STF; e (iv) natureza supralegal, que viria com o posicionamento isolado do Min. Sepúlveda Pertence. ${ }^{43}$

Com a EC n 45/2004, o impasse na posição do STF encerrou-se pela via legislativa, conferindo status constitucional somente àqueles tratados de direitos humanos que fossem internalizados por meio do procedimento de aprovação de emendas constitucionais. Porém, restava ainda o dissenso para a situação anterior até 2004 . A inserção do art. $5^{\circ}, \S 3^{\circ}$ motivou uma nova revisão do posicionamento do STF sobre a hierarquia dos tratados de direitos humanos que permanece até os dias de hoje. No julgamento do RE n 466.343, que trouxe novamente a questão do depositário infiel, a maioria dos ministros defendeu a posição antes adotada pelo Min. Sepúlveda Pertence, ou seja, os tratados internacionais de direitos humanos possuem natureza supralegal, estando abaixo da Constituição, mas acima de toda e qualquer lei. ${ }^{44}$ Essa virada de entendimento partiu do Min. Gilmar Mendes, que, resgatando o voto do Min. Pertence, entendeu que, já que o Brasil não fez nenhuma reserva ao Pacto Civil, ao Pacto de San Jose e à Convenção Americana, ambos no ano de 1992, não há mais base legal para a prisão civil do depositário infiel (então objeto do debate), "pois o caráter especial desses diplomas internacionais sobre direitos humanos lhes reserva lugar específico

$39 \quad$ FACHIN, Luiz Edson. Notas para um ensaio sobre a posição jurídica dos tratados internacionais de direitos humanos no Brasil após a reforma constitucional. In: PRONER, Carol; CORREAS, Óscar (Coord.). Teoria crítica dos direitos humanos. Belo Horizonte: Fórum, 2011. p. 157.

40 Sobre as diversas interpretações, cf. SCHIER, Paulo Ricardo. Hierarquia constitucional dos Tratados Internacionais de Direitos Humanos e Emenda Constitucional 45 - Tese em favor da incidência do tempus regit actum. 2008. Disponível em: http://www.publicadireito.com.br/ conpedi/ manaus/arquivos/anais/XIVCongresso/06 3.pdf. Acesso em: 28 nov. 2017.

41 STF, HC 79.785. Rel. Min. Sepúlveda Pertence, Julg. 29.03.2000.

42 O STF julgou o caso por maioria dos votos, negando provimento ao recurso.

43 Sobre o tema, cf. MESSA, Ana Flávia; FRANCISCO, José Carlos. Tratados internacionais sobre direitos humanos e poder constituinte. In: PAGLIARINI, Alexandre Coutinho; DIMOULIS, Dimitri (Coord.). Direito constitucional e internacional dos direitos humanos. Belo Horizonte: Fórum, 2012. p. 241-276.

44 Para uma análise dos fundamentos dessa decisão, cf. MAUÉS, Antônio Moreira. Supralegalidade dos tratados internacionais de direitos humanos e interpretação constitucional. In: SOARES, Mário Lúcio Quintão; SOUZA, Mércia Cardoso de (Coord.). A interface dos direitos humanos com o direito internacional. Tomo I, Belo Horizonte: Fórum, 2015. p. 137-162. 


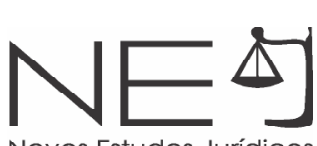

no ordenamento jurídico, estando abaixo da Constituição, porém acima da legislação interna" ${ }^{45}$ Diante disso, a Corte passou a adotar a teoria do duplo estatuto dos tratados de direitos humanos, conferindo natureza constitucional aos que forem aprovados pelo procedimento especial do art. $5^{\circ}$, $\S 3^{\circ}$, bem como considerando de caráter supralegal para os demais, sejam anteriores ou posteriores à EC $n^{\circ} 45 / 2004$ e que tenham sido aprovados pelo rito comum. ${ }^{46}$

Nesse sentido, tem-se que $0 \$ 3^{\circ}$ do art. $5^{\circ}$ mantém a existência de um bloco de constitucionalidade, porém mais restrito, algo que foi muito criticado pela doutrina mais garantista justamente devido a esse menor espaço para a recepção de tratados internacionais de direitos humanos. ${ }^{47}$ Exemplo disso foi a manifestação feita por Cançado Trindade, em seu voto em separado no Caso Damião Ximenes vs. Brasil, da Corte Interamericana de Direitos Humanos. Nesse voto, ele expressou sua indignação com a aprovação do $\S 3^{\circ}$ do art. $5^{\circ}$ da Constituição de 1988 , afirmando que o dispositivo busca outorgar, de forma "bisonha", status constitucional somente aos tratados que se submetam ao rito especial descrito. Diante disso, critica essa modificação constitucional, classificando-a de "mal concebido, mal redigido e mal formulado [o dispositivo legal]", e que representa um "lamentável retrocesso em relação ao modelo aberto consagrado pela Constituição Federal de 1988", o qual ele teve uma participação ativa por meio de uma proposta à Assembleia Nacional Constituinte de 1988.48

Ainda que o STF tenha se pronunciado a respeito e que a celeuma jurídica - ao menos aparentemente - tenha sido resolvida, o fato é que, para autores como Ingo Sarlet, não há como dissociar o $\$ 3^{\circ}$ do $\S 2^{\circ}$, ambos do art. $5^{\circ}$ da Constituição de 1988, porque um complementa o outro, exigindo uma exegese conjunta. Assim, o autor, desde um primeiro momento, afasta a recepção constitucional dos tratados internacionais de direitos humanos anteriores à EC $n^{\circ} 45 / 2004$ devido a sua clara incompatibilidade de rito para isso. Por outro lado, Sarlet aplica a técnica da interpretação

$45 \quad$ Vd. voto Min. Gilmar Mendes, RE n 466.343.

46 Cf. LOPES, Dalliana Vilar; LOPES, Gills Vilar. A internalização dos tratados sobre Direitos Humanos na ordem jurídica brasileira e a problemática da ordem internacional. Universitas Relações Internacionais, Brasília, v. 14, n. 1, p. 51-59, jan./jun. 2016.

47 Nesse sentido, cf. MEYER-PFLUG, Samantha Ribeiro. A internacionalização do Direito Constitucional Brasileiro. In: PAGLIARINI, Alexandre Coutinho; DIMOULIS, Dimitri (Coord.). Direito constitucional e internacional dos direitos humanos. Belo Horizonte: Fórum, 2012. p. 283; e CARVALHO, Feliciano. A natureza jurídica constitucional de todos os tratados internacionais de direitos humanos: análise da supralegalidade e da inconsciência do Supremo Tribunal Federal brasileiro. In: Anais do XXII encontro nacional do CONPEDI, 2013, p. 137-157.

48 Cançado Trindade continua com sua contundente crítica nos seguintes termos: "No tocante aos tratados anteriormente aprovados, cria um imbróglio tão a gosto de publicistas estatocêntricos, insensíveis às necessidades de proteção do ser humano; em relação aos tratados a aprovar, cria a possibilidade de uma diferenciação tão a gosto de publicistas autistas e míopes, tão pouco familiarizados, — assim como os parlamentares que lhes dão ouvidos, — com as conquistas do Direito Internacional dos Direitos Humanos. Este retrocesso provinciano põe em risco a inter-relação ou indivisibilidade dos direitos protegidos no Estado demandado (previstos nos tratados que o vinculam), ameaçando-os de fragmentação ou atomização, em favor dos excessos de um formalismo e hermetismo jurídicos eivados de obscurantismo. A nova disposição é vista com complacência e simpatia pelos assim chamados "constitucionalistas internacionalistas", que se arvoram em jusinternacionalistas sem chegar nem de longe a sê-lo, porquanto só conseguem vislumbrar o sistema jurídico internacional por meio da ótica da Constituição nacional. Não está sequer demonstrada a constitucionalidade do lamentável parágrafo 3 do artigo 5 , sem que seja minha intenção pronunciarme aqui a respeito; o que sim, afirmo no presente Voto, — tal como o afirmei em conferência que ministrei em 31.03.2006 no auditório repleto do Superior Tribunal de Justiça (STJ) em Brasília, ao final de audiências públicas perante esta Corte que tiveram lugar na histórica Sessão Externa da mesma recentemente realizada no Brasil, - é que, na medida em que o novo parágrafo 3 do artigo 5 da Constituição Federal brasileira abre a possibilidade de restrições indevidas na aplicabilidade direta da normativa de proteção de determinados tratados de direitos humanos no direito interno brasileiro (podendo inclusive inviabilizá-la), mostra-se manifestamente incompatível com a Convenção Americana sobre Direitos Humanos (artigos 1(1), 2 e 29)" (Voto em separado, Caso Damião Ximenes vs. Brasil, parágrafos 30 e 31. Disponível em: http:// www.corteidh.or.cr/docs/casos/ articulos/seriec_149_por.pdf. Acesso em: 20 jun. 2018). 
conforme, entendendo que $0 \S 3^{\circ}$ do art. $5^{\circ}$ será constitucional quando for compreendido para assegurar hierarquia constitucional (ao menos em sentido material) aos tratados em matéria de direitos humanos já incorporados antes da EC n 45/2004, bem como hierarquia formal e material aos tratados eventualmente incorporados pelo rito constante no $\$ 3^{\circ}$ do art. $5^{\circ}$. Já os tratados anteriores à $\mathrm{EC} \mathrm{n}^{\circ} 45 / 2004$, para terem hierarquia constitucional formal, devem ser aprovados pelo rito previsto no $\$ 3^{\circ}$ do art. $5^{\circ}$ de todos modos. ${ }^{49}$

A noção de bloco de constitucionalidade já vinha sendo usada antes da EC nº 45/2004 como uma ideia de "constituição total" a partir da ordem expressa e positivada, bem como todos os seus princípios orientadores e inerentes..$^{50}$ No entanto, negou-se reiteradas vezes a sua hierarquia constitucional, algo que, pelo menos, ficou mais objetivo após a EC nº 45/2004. Desde então, o bloco de constitucionalidade no sistema brasileiro adquiriu uma nova dimensão, fazendo com que o ordenamento constitucional em sentido formal, material e hierárquico represente a reunião de diplomas normativos diversos e não consolidados organicamente em um único documento. Isso diretamente impacta sobre o controle de constitucionalidade ${ }^{51}$ e no controle de convencionalidade, tanto concentrado ${ }^{52}$ como difuso ${ }^{53}$, algo ainda pouco aventado na doutrina, e menos ainda na jurisprudência.

Diante de tanta polêmica, Piovesan traz uma visão que compatibiliza o decidido pelo STF e a doutrina, afirmando que nem o art. $5^{\circ} \S 3^{\circ}$ seria inconstitucional, nem os tratados de direitos humanos aprovados pelo rito simples seriam como uma lei ordinária. Para a autora, não importa se o instrumento foi incorporado ao ordenamento antes ou depois da EC $n^{\circ} 45 / 2004$, o que efetivamente deve ser levado em consideração é o seu conteúdo, pois todos seriam materialmente constitucionais. No entanto, nos casos de tratados aprovados pelo rito especial, eles seriam material e formalmente constitucionais e, sendo assim, não poderiam ser denunciados e seriam incluídos no rol de cláusulas pétreas, conformando a petrificação dos tratados que se submetessem a esse procedimento qualificado. ${ }^{54}$

49 SARLET, Ingo Wolfgang. Algumas normas sobre a incorporação e a hierarquia dos tratados internacionais em matéria de Direitos Humanos na ordem jurídica brasileira, especialmente em face do novo $\S 3^{\circ}$ do art. $5^{\circ}$ da Constituição de 1988. Revista de Direito Administrativo. v. 245 , 2007. p. 74; SARLET, Ingo Wolfgang. Considerações a respeito das relações entre a Constituição Federal de 1988 e os tratados internacionais de direitos humanos. Revista TST. v. 77, n 4, out./dez., 2011. p. 166.

50 Nesse sentido, vd. ADI n 595/ES, Rel. Min. Celso de Mello.

51 MESSA, Ana Flávia; FRANCISCO, José Carlos. Tratados internacionais sobre direitos humanos e poder constituinte. In: PAGLIARINI, Alexandre Coutinho; DIMOULIS, Dimitri (Coord.). Direito constitucional e internacional dos direitos humanos. Belo Horizonte: Fórum, 2012. p. 263.

52 Sobre o tema, cf. MAZZUOLI, Valério de Oliveira. O controle jurisdicional da convencionalidade das leis no Brasil. In: SOUSA, Marcelo Rebelo et al. (Coords.). Estudos em homenagem ao Prof. Doutor Jorge Miranda, v. III (Direito constitucional e justiça constitucional). Coimbra: Coimbra Editora, 2012, p. 759-776; e MAZZUOLI, Valério de Oliveira. Podem os tratados de direitos humanos não "equivalentes" às emendas constitucionais servir de paradigma ao controle concentrado de convencionalidade? RDU. v. 12, $n^{\circ}$ 64, p. 222-229, jul./ago., 2015.

53 CALETTI, Leandro; STAFFEN, Marcio Ricardo. O controle de convencionalidade pela via difusa como forma de otimização e exigibilidade dos direitos humanos. Revista da AGU, Brasília-DF, v. 14, n. 04, p. 133-156, out./dez. 2015; CALETTI, Leandro. O controle difuso da convencionalidade e os direitos humanos no Brasil. Revista IIDH, n. 64, p. 189-214, jul./dic., 2016.

PIOVESAN, Flávia. Direitos humanos e o direito constitucional internacional. São Paulo: Saraiva, 2006. p. 77. 
Entretanto, é inegável que o atual tratamento constitucional dos tratados internacionais ( $\$ 3^{\circ}$ do art. $5^{\circ}$ ), aliado à posição do STF, debilita a consolidação e a realização dos direitos humanos no plano interno, criando um efeito-dominó que atinge boa parte do Poder Judiciário - com magistrados que ainda não reconhecem os direitos humanos como regras a serem aplicadas no plano interno -, dos governantes - que continuam violando sistematicamente diversos direitos objeto de documentos internacionais e que se recusam a cumprir integralmente as sentenças proferidas por tribunais internacionais ${ }^{55}$, como é o caso da Corte Interamericana, e também da sociedade, que julga que os direitos humanos, além de "não existirem", só serviriam para "os bandidos"56, deslegitimando os valores neles inculcados.

\section{OS DIÁlOGOS ENTRE CORTES E A RETROALIMENTAÇÃO DA ORDEM JURÍDICA INTERNACIONAL E INTERNA: ALGO AINDA A CONQUISTAR}

A doutrina estrangeira aborda já há algum tempo que a ordem internacional dos direitos humanos se sobrepõe à interna dos países, isso porque, atendendo à pretensão de universalidade dos direitos humanos para todas as pessoas, independentemente dos países em que estejam, a partir do momento que Estados aderem a tratados internacionais que disponham sobre esses direitos, eles adquirem obrigações erga omnes, submetendo-se à normativa internacional, incluindo, aqui, as suas constituições. ${ }^{57}$ É nessa linha que Peter Häberle afirma que, se antes a interpretação se fazia de acordo com a Constituição, agora essa interpretação se pauta nos direitos humanos, ou seja, o direito interno - a Constituição - deve ser interpretado segundo o Direito Internacional dos direitos humanos. ${ }^{58}$

Nesse sentido, adere-se à ideia de Marcelo Neves de que os direitos humanos têm o objetivo de se afirmar não só perante o âmbito internacional, mas principalmente nas diversas ordens estatais, assim como diante da pluralidade de ordens extraestatais em que expectativas normativas têm relevância estrutural. Para tanto, os direitos humanos exigem uma institucionalização de procedimentos abertos à heterogeneidade cultural, complexidade sistêmica e pluralidade discursiva da sociedade mundial, que possam garanti-los. ${ }^{59}$

Ocorre que há Estados que sequer aderiram aos princípios do Estado democrático de Direito, negando amplamente os direitos humanos mediante exclusão jurídica de boa parte desses direitos, ou mesmo reconhecendo-os como direitos fundamentais, mas sem que a Constituição possua força

\footnotetext{
55 Sobre o tema, cf. PEREIRA, Taís Mariana Lima. O cumprimento das decisões da corte interamericana de direitos humanos pelo Brasil. EJJL. Chapecó, v. 14, n. 2, p. 315-348, jul./dez. 2013.

56 Cf. CALDEIRA, Teresa Pires do Rio. Direitos Humanos ou "Privilégios de Bandidos"? Desventuras da Democratização Brasileira. Novos Estudos CEBRAP - SP, nº. 30, p. 162-174. julho/91. Disponível em: http://novosestudos.org.br/v1/files/uploads/contents/64/20080624_ direitos_humanos_ou_privilegios_de_bandidos.pdf. Acesso em: 10 jun. 2018.

57 CANTOR, Ernesto Rey. Controles de convencionalidad de las leyes. Biblioteca Jurídica del Instituto de Investigaciones Jurídicas de la UNAM. 2011. p. 226. Disponível em: https://archivos.juridicas.unam.mx/www/bjv/libros/6/2562/16.pdf. Acesso em: 22 jun. 2018.

58 HÄBERLE, Peter. El Estado constitucional. México: UNAM, 2001. p. 185.

59 NEVES, Marcelo. A Força Simbólica dos Direitos Humanos. Revista Brasileira de Direito Público RBDP. Belo Horizonte, n. 3 , ano 1 Outubro/ Dezembro, 2003. Disponível em: <http://www.bidforum.com.br/bid/PDI0006.aspx?pdiCntd=12542>. Acesso em: 26 jun. 2018.
} 
normativa. ${ }^{60}$ No caso brasileiro, isso também é relevante, pois o país não ofereceu, em seu momento, um ambiente propício para a implantação do positivismo tal como idealizado, que consequentemente impactou na construção do Estado de Direito. ${ }^{61}$ Nesse sentido, sendo o positivismo filosófico algo social, coletivo, que se ampara no fato social e nas suas relações empíricas ${ }^{62}$, e o positivismo jurídico como algo da esfera do "dever ser", com validade e vigência de normas (com forte conotação ao formalismo) ${ }^{63}$, tem-se que o Brasil, nas palavras de Emerson Gabardo, "nunca possuiu as circunstâncias adequadas para a implantação de um ideário tão exato, coerente e equitativo como é o positivista [em suas vertentes filosófica e jurídica]", uma vez que a sociedade brasileira não tinha, e ainda carece de uma mentalidade coletiva, fazendo com que o individual prevaleça sobre o público, e muito menos impessoal, o que causou o apego ao formalismo, mas somente quando o estabelecido esteja de acordo com os seus interesses. ${ }^{64}$ Nessa linha, o Estado de Direito é tido aqui como a visão formal do Direito, preocupado em afirmar um sistema jurídico que seja formalmente garantidor da previsibilidade jurídica a partir da ideia de uma lei que também submeta aos seus governantes, mas que também estabelece direitos para além do aspecto formal-negativo, atraindo uma atuação estatal garantista, não se limitando à sua versão liberal. Em sendo assim, o Brasil tardou para se tornar um Estado de Direito, justamente porque a sua realidade sempre caminhou em sentido contrário ao de sua legislação, pois desde a Constituição de 1824 já havia a previsão de direitos, tal como já descrito nesse ensaio, mas isso não foi suficiente para diminuir a distância entre a teoria e a prática. Ou seja, as ideias mais fundamentais de um Estado de Direito já estavam se solidificando, mas a sua aplicação ainda - até os dias de hoje permanece muito seletiva. ${ }^{65}$

60 NEVES, Marcelo. A Força Simbólica dos Direitos Humanos. Revista Brasileira de Direito Público RBDP. Belo Horizonte, n. 3 , ano 1 Outubro/ Dezembro, 2003. Disponível em: <http://www.bidforum.com.br/bid/PDI0006.aspx?pdiCntd=12542>. Acesso em: 26 jun. 2018. O autor também destaca que pode haver Constituições em Estados democráticos de Direito com força normativa, e que isso pode causar a cristalização de práticas de agentes estatais contrários aos direitos humanos assegurados como fundamentais. Nesse sentido, ele se utiliza das lições de Luhmann para afirmar que os direitos humanos são tanto mais conhecidos e afirmados quando são mais graves e frequentes as violações contra eles.

61 Admite-se que esse debate poderia ser objeto de um longo trabalho que ultrapassa muito a proposta aqui constante. Dessa forma, mesmo arriscando-se ser muito breve nas fundamentações dos argumentos, optou-se ainda assim por fazer constar esse detalhe por entender que é importante para as conclusões que serão expostas.

62 Cf. COMTE, Augusto. Discurso sobre o espírito positivo. [s.d.]. p. 40-41. Disponível em: <http://www.ebooksbrasil.org/adobeebook/comte.pdf> Acesso em: 22 jun. 2018; HESPANHA, Antônio Manuel. Cultura jurídica europeia - Síntese de um milênio. Coimbra: Almedina, 2012. p. 398 e ss.

63 KELSEN, Hans. Teoria pura do Direito. 6. ed. Rio de Janeiro: Martins Fontes, 1998. p. 79 e ss.

64 GABARDO, Emerson. Interesse público e subsidiariedade: o Estado e a sociedade civil para além do bem e do mal. Belo Horizonte: Fórum, 2009. p. 78-85.

65 GABARDO, Emerson. Interesse público e subsidiariedade: o Estado e a sociedade civil para além do bem e do mal. Belo Horizonte: Fórum, 2009. p. $84-90$ 
É essa aplicação seletiva do Direito interno, principalmente no que tange aos direitos fundamentais, que enfraquece o discurso e prejudica o sistema brasileiro em sua comunicação com o Direito Internacional, principalmente com os direitos humanos. Isso pode ser ilustrado com o paradoxo atual da cada vez maior procura dos sistemas internacionais de proteção dos direitos humanos pelos cidadãos brasileiros ${ }^{66}$, mas ainda da baixa adesão a essa ordem jurídica internacional de direitos pelas Cortes e magistrados nacionais.

Como forma de ilustrar o que está sendo aventado, optou-se por fazer uma pesquisa jurisprudencial no sítio web do STF com alguns vocábulos referentes ao objeto em estudo. ${ }^{67}$ No caso da expressão "sistema interamericano", houve 36 resultados, sendo que 26 faziam menção à ausência do Min. Toffoli no julgamento do caso devido a um evento sobre o sistema interamericano; outro versou sobre extradição (caso Cesare Batisti68) e outros 9 sobre prisões cautelares e excesso de prazo, em que se invoca a Convenção Americana. Já com a expressão "Convenção Americana", o resultado aumenta para 279 acórdãos e 2 repercussões gerais, tendo temas variados, que vão desde extradição; prisões cautelares; violência em estabelecimentos prisionais (invocando o sistema onusiano também, no RE 58025269, em que se fixou a indenização de um preso devido à situação degradante durante o cumprimento de sua pena); crimes ambientais (com ampla menção a tratados internacionais); caso do depositário infiel de valor da Fazenda Nacional (ADI 105570), em que o STF traz o precedente da Corte Interamericana; casos sobre tortura e outros que invocam a Convenção para amparar o direito à ampla defesa, não exatamente na ementa do acórdão; dentre outros casos.

Já quando pesquisado "Corte Interamericana", há 44 acórdãos. Quando realmente há a abordagem de jurisprudência interamericana (porque em alguns casos o resultado "corte" e "interamericana" aparecem separadamente, não indicando algo que seja o foco aqui), há alguns interessantes, como o HC 124.306, Rel. Min. Marco Aurélio71, em que se aborda o tema do aborto e

66 Segundo levantamento feito por Flávia Piovesan, até julho de 2016, dezesseis casos haviam sido encaminhados à Corte Interamericana de Direitos Humanos contra o Estado brasileiro, e mais de 130 casos haviam sido submetidos à Comissão Interamericana (Cf. PIOVESAN, Flavia. Brasil e o Sistema Interamericano de Proteção dos Direitos Humanos. In: _. Temas de Direitos Humanos. 10. ed. São Paulo: Saraiva, 2017. p. 109. Além disso, Eduardo Szazi aponta para uma tendência de crescimento dessa procura pelos sistemas internacionais de proteção pelos brasileiros (cf. SZAZI, Eduardo. A violência estatal perante os sistemas internacionais de Direitos Humanos. Artigo não publicado, 2017. p. 8).

67 Pesquisa realizada em 15 de setembro de 2017. Decidiu-se manter os resultados e as conclusões devido à utilização de dados também de 2016 e 2017 referentes à procura dos sistemas internacionais de proteção dos direitos humanos pelos cidadãos brasileiros. Assume-se que pode haver imprecisões nos dados, considerando que a pesquisa foi feita simplesmente pelo sistema do STF, podendo este fornecer informações parciais.

68 BRASIL, Supremo Tribunal Federal. Extradição 1085. Requerente: Governo da Itália. Extraditado: Cesare Battisti. Relator Min. Cezar Peluso. Brasília, 16 de dezembro de 2009. Disponível em: < http://stf.jus.br/portal/jurisprudencia/listarJurisprudencia.asp?s1=\%28CESARE+BATTIST I\%29\&base=baseAcordaos\&url=http://tinyurl.com/y3mdoeyo>. Acesso em: 08 out. 2019.

69 BRASIL, Supremo Tribunal Federal. Recurso Extraordinário n 580252. Recorrente: Anderson Nunes da Silva. Recorrido: Estado de Mato Grosso do Sul. Relator Min. Alexandre de Moraes. Brasília, 16 de fevereiro de 2017. Disponível em: <http://portal.stf.jus.br/processos/detalhe. asp?incidente=2600961>. Acesso em: 08 out. 2019.

70 BRASIL. Supremo Tribunal Federal. Ação Direta de Inconstitucionalidade n 1055. Requerente: Confederação Nacional da Indústria. Requerido: Presidente da República. Brasília, 15 de dezembro de 2016. Disponível em: <http://portal.stf.jus.br/processos/detalhe.asp?incidente=1584564>. Acesso em: 08 out. 2019.

71 BRASIL. Supremo Tribunal Federal. Habeas Corpus 124.306. Paciente: Edilson dos Santos y Rosemere Aparecida Ferreira. Coator: Superior Tribunal de Justiça. Relator Min. Marco Aurélio. Brasília, 29 de novembro de 2016. Disponível em: http://portal.stf.jus.br/processos/detalhe. asp? Incidente =4637878. Acesso em: 08 out. 2019. 
a prisão oriunda dessa prática..$^{72}$ Há também a ADPF 347, Rel. também do Min. Marco Aurélio ${ }^{73}$, em que se debateu a aplicação do que se chama de "estado das coisas inconstitucional" sobre o sistema prisional, mas que não aborda jurisprudência interamericana especificamente, senão o Pacto Civil e a Convenção Interamericana. Outro caso que resultou da pesquisa é o RE 592.58174 , em que se trata o tortuoso tema dos estabelecimentos de correção de adolescentes, citando o caso em que o Brasil respondeu na Corte Interamericana que envolveu o complexo do Tatuapé - FEBEM. Há a ADI 481575 que versa sobre as biografias não autorizadas, em que há também menção à jurisprudência da Corte Interamericana; e o HC 115.53976, que discute justamente um caso em que o Brasil foi condenado na Corte junto ao estado de Rondônia, envolvendo a penitenciária Urso Branco. ${ }^{77}$ Outro resultado que cita jurisprudência da Corte Interamericana é o HC 110.18578, que discute a prática de crimes militares em tempos de paz e o direito ao juiz natural, havendo outras decisões sobre essa temática; bem como o RE 511.96179, em que se declarou a não obrigatoriedade do diploma de jornalismo para o exercício da profissão, amparando-se em decisões da Corte Interamericana nesse sentido, além de uma opinião consultiva (5-85, de 13 de novembro de 1985).

Portanto, é possível verificar que ainda não se percebe tanto impacto das decisões da Corte Interamericana no STF ou da legislação internacional de direitos humanos, mesmo considerando que muitos julgamentos emblemáticos não constaram do levantamento, como é a ADPF $153^{80}$ (referente à aplicação da Lei da Anistia), ocasião em que o STF, além de não se alinhar com a jurisprudência interamericana e de atender à sentença proferida pela Corte contra o Estado brasileiro, também - no entendimento defendido nesse ensaio - não observou o princípio pro homine, privilegiando uma norma que vai de encontro com muitos direitos humanos, inclusive fundamentais. ${ }^{81}$ Já no que se refere à legislação internacional, aos sistemas internacionais de proteção dos direitos humanos e às Cortes estaduais, a distância é ainda maior.

72 Aqui o STF declarou que o aborto praticado até o $3^{\circ}$ mês não deveria ser considerado crime, o que gerou grande repercussão e que, inclusive a estátua da Lex na frente da Corte foi vandalizada com tinta vermelha, representando sangue.

73 BRASIL. Supremo Tribunal Federal. Arguição de descumprimento de preceito fundamental $n^{\circ} 347$. Requerente: Partido Socialismo e Liberdade - PSOL. Requerido: União Federal. Relator Min. Marco Aurélio. Brasília, 09 de setembro de 2015. Disponível em: http://portal.stf.jus.br/ processos/ detalhe.asp?incidente=4783560. Acesso em: 08 out.2019.

74 BRASIL. Supremo Tribunal Federal. Recurso Extraordinário n 592.581. Recorrente: Ministério Público do Estado do Rio Grande do Sul. Recorrido: Estado do Rio Grande do Sul. Relator Min. Ricardo Lewandowski. Brasília, 13 de agosto de 2015. Disponível em: http://portal.stf. jus.br/processos/ detalhe.asp?incidente=2637302. Acesso em: 08 out. 2019. BRASIL. Supremo Tribunal Federal. Ação Direta de Inconstitucionalidade $n^{\circ} 4815$. Requerente: Associação Nacional dos Editores de Livros ANEL. Requerido: Presidente da República. Relatora Min. Carmen Lúcia. Brasília, 10 de junho de 2015. Disponível em: <http://portal.stf.jus.br/ processos/ detalhe.asp?incidente=4271057>. Acesso em: 08 out. 2019.

76 BRASIL. Supremo Tribunal Federal. Habeas Corpus n 115.539 . Paciente: Eliton Alves Alfaia. Coator: Superior Tribunal de Justiça. Relator Min. Luiz Fux. Brasília, 03 de setembro de 2013. Disponível em: http://portal.stf.jus.br/processos/detalhe.asp?incidente=4318900. Acesso em: 08 out. 2019.

77 Aqui vale lembrar que o Brasil foi novamente denunciado à Comissão Interamericana no ano passado por más condições em presídios também em Rondônia, mas agora na Casa de Detenção de Ariquemes.

78 BRASIL. Supremo Tribunal Federal. Habeas Corpus $\mathrm{n}^{\circ}$ 110.185. Paciente: Ademilson Moreira de Almeida. Coator: Superior Tribunal Militar. Relator Min. Celso de Mello. Brasília, 14 de maio de 2013. Disponível em: http://portal.stf.jus.br/processos/detalhe.asp?incidente=4134368. Acesso em: 08 out. 2019.

79 BRASIL. Supremo Tribunal Federal. Recurso Extraordinário n 511.961. Recorrente: Sindicato das Empresas de Rádio e Televisão no Estado de São Paulo - SERTESP. Recorrido: União Federal. Relator Min. Gilmar Mendes. Brasília, 17 de junho de 2009. Disponível em: http://portal. stf.jus.br/processos/ detalhe.asp?incidente=2469175. Acesso em: 08 out. 2019

80 BRASIL. Supremo Tribunal Federal. Arguição de Descumprimento de Preceito Fundamental $n^{\circ} 153$. Requerente: Conselho Federal da Ordem dos Advogados Do Brasil - OAB. Requerido: Presidente da República. Relator Min. Luiz Fux. Brasília, 29 de abril de 2010. Disponível em: http://portal.stf.jus.br/processos/detalhe.asp?incidente=2644116. Acesso em: 08 out. 2019

81 Sobre essa polêmica decisão, cf., por todos, ROTHEMBURG, Walter Claudius. Controle de constitucionalidade e controle de convencionalidade: o caso brasileiro da lei da anistia. In: PAGLIARINI, Alexandre Coutinho; DIMOULIS, Dimitri (Coord.). Direito constitucional e internacional dos direitos humanos. Belo Horizonte: Fórum, 2012. p. 333-359. 
Como exemplo, realizou-se a mesma pesquisa acima, mas no sistema de busca de jurisprudência do Tribunal de Justiça do estado do Paraná. ${ }^{82}$ Com a consulta da expressão "Convenção Americana", há 36 resultados. Entre eles, temáticas trazidas pelas partes, como a prática do crime de desacato e diversos Habeas Corpus que pedem a ordem com base na Convenção, art. 13.83 Em todos os casos pesquisados, a ordem não é concedida ${ }^{84}$, porque se entende que a legislação nacional mantém o crime de desacato no ordenamento jurídico, não decidindo que a Convenção deva prevalecer sobre o disposto no Código Penal. Há ainda casos de conflito de competência em situações abordando a violência doméstica - se é do juízo criminal ou do juizado criminal85 -, e nesses casos somente há a menção tanto da Convenção Americana como a de Belém do Pará, específica sobre a temática desse tipo de violência; bem como outros casos versando sobre a não realização da audiência de custódia no prazo de 90 dias ${ }^{86}$, em que as decisões, inclusive, estabelecem que, segundo o art. 312 do Código de Processo Penal, já existem garantias ao preso provisório, o que "supre" a necessidade de apresentação do preso à autoridade judicial. ${ }^{87}$

Já pesquisando, ainda no âmbito do TJ-PR, a expressão "Corte Interamericana", há 22 resultados, sendo um deles sobre a condenação do Brasil por realizar interceptações telefônicas ilegais de integrantes do Movimento Sem-Terra, envolvendo o Governo do Paraná. ${ }^{88}$ Nessa decisão ${ }^{89}$, o TJ-PR declarou que não havia direito de indenização perante o Governo do Paraná, considerando que os autores já haviam recebido indenização por conta da condenação na Corte Interamericana, sendo que não havia fatos novos que motivassem uma nova indenização. Nesse sentido, o TJ-PR entendeu que não havia interesse legítimo na solução da demanda por parte dos autores, condenando-os ao ônus da sucumbência.

82 Os esclarecimentos feitos sobre a pesquisa realizada no sistema do STF e sobre a abrangência temporal também são aplicáveis aqui, ou seja, a pesquisa realizada em 15 de setembro de 2017 e se decidiu manter os resultados e as conclusões devido à utilização de dados também de 2016 e 2017 referentes à procura dos sistemas internacionais de proteção dos direitos humanos pelos cidadãos brasileiros. Assume-se que pode haver imprecisões nos dados, considerando que a pesquisa foi feita simplesmente pelo sistema do TJ-PR, podendo este fornecer informações parciais.

83 Artigo referente à liberdade de expressão.

84 Como exemplo, cite-se: BRASIL. Tribunal de Justiça do Estado do Paraná. Apelação n 0001795-80.2011.8.16.0019. Apelante: Marcelo Pinheiro. Apelado: Ministério Público do Estado do Paraná. Relator: Des. Luís Carlos Xavier. Curitiba, 30 de setembro de 2019 . Disponível em: https://portal.tjpr.jus.br/jurisprudencia/j/4100000010167841/Ac\%C3\%B3rd\%C3\%A3o-0001795-80.2011.8.16.0019\#. Acesso em: 08 out. 2019.

85 Como exemplo, cf. BRASIL. Tribunal de Justiça do Estado do Paraná. Conflito de competência n ${ }^{\circ} 1321279-2$. Relator: Des. Telmo Cherem. Curitiba, 20 de maio de 2015. Disponível em: https://portal.tjpr.jus.br/jurisprudencia/j/11908502/Decis\%C3\%A3o\%20monocr\%C3\%A1tica-1321279-2. Acesso em: 08 out. 2019.

86 Como exemplo, cf. BRASIL. Tribunal de Justiça do Estado do Paraná. Habeas Corpus $\mathrm{n}^{\circ}$ 0044543-77.2017.8.16.0000. Paciente: Adam Felix Souza dos Santos. Coator: Juízo Criminal de Tibagi. Relator: Des. Maria José de Toledo Marcondes Teixeira. Curitiba, 25 de janeiro de 2018. Disponível em: <https://portal.tjpr.jus.br/jurisprudencia/j/4100000005206951/Ac\%C3\%B3rd\%C3\%A3o-0044543-77. 2017.8.16.0000\#integra_4100000005206951>. Acesso em: 08 out. 2019.

87 Portanto, nas linhas desse ensaio, há aqui uma possível violação da Convenção, com a chancela do Poder Judiciário estadual paranaense. Trata-se de um julgamento de 2016, o que denota a postura pouco aberta dessa corte ao Sistema Interamericano de proteção aos direitos humanos. Pode-se, inclusive, extrair desse caso que há a direta elevação do CPP diante da Convenção, o que não poderia ser, se for pensar segundo a hierarquia normativa aplicada pelo STF.

88 Caso Escher e outros vs. Brasil.

89 BRASIL. Tribunal de Justiça do Estado do Paraná. Apelação Cível n 965944-3. Apelante: José Adalberto Maschio. Apelado: Estado do Paraná. Relator Des. Dimas Ortêncio de Melo. Curitiba, 12 de março de 2013. Disponível em: https://portal.tjpr.jus.br/jurisprudencia/j/11424634/ Ac\%C3\%B3rd\% C3\%A3o-965944-3. Acesso em: 08 out. 2019. 
As decisões restantes versam somente sobre conflitos de competência entre juízo criminal e juizado criminal em casos de violência doméstica, limitando-se à menção da Corte Interamericana.

Diante desse cenário, não se pode afirmar que há diálogo entre o Sistema Interamericano e a legislação internacional de direitos humanos e a jurisdição constitucional brasileira, nem mesmo com outro sistema internacional, evidenciando, inclusive, uma resistência a essa maior interação entre a ordem interna e internacional, o que dificulta muito a proteção multinível desses direitos.

\section{ALGUNS FATORES QUE INFLUENCIAM NO DIÁLOGO DAS CORTES INTERNAS E INTERNACIONAIS}

Em um trabalho muito interessante, José Ricardo Cunha et al. realizam uma pesquisa empírica com magistrados de primeira instância da Comarca da Capital do Tribunal de Justiça do estado do Rio de Janeiro para investigar o grau de justiciabilidade (efetividade) dos direitos humanos na tutela jurisdicional..$^{90}$ Ainda que seja um estudo de 2005, é um indicativo de alguns fatores que podem influenciar sobre o diálogo [ou a falta dele] entre cortes internas e internacionais, bem como com a legislação de direitos humanos. ${ }^{91}$

Para realizar a pesquisa, os autores optaram por duas vertentes, sendo uma teórica e outra prática. Na teórica, utilizou-se um estudo sistemático dos fundamentos jurídicos, filosóficos e políticos dos direitos humanos, a partir das obras de Carlos Santiago Nino, Antonio Enrique Pérez Luño, Chaïm Perelman e Robert Alexy. Já na vertente empírica, foi feito um levantamento em 225 das 244 varas em funcionamento de primeira instância do Tribunal de Justiça na cidade do Rio de Janeiro, e logo foi aplicado um questionário, a fim de investigar o modo que cada magistrado responsável pela prestação jurisdicional naquela vara concebe e aplica os direitos humanos. O questionário também procurou levantar o nível de formação dos juízes na área de direitos humanos.92

Em apertada síntese dos resultados, foi apurado que 84\% dos magistrados responderam que não tiveram a disciplina de Direitos Humanos na graduação. Dentre as respostas afirmativas, apenas 4\% dos juízes tiveram a disciplina como obrigatória, enquanto para 12\% ela havia sido opcional. Assim, mesmo diante da escassa oferta da disciplina nas faculdades, mas considerando a relevância do tema, foi perguntado aos juízes sobre o seu interesse pelos estudos relacionados aos direitos humanos. Boa parte dos juízes demonstrou interesse em fazê-lo (cerca de 73\%).

90 CUNHA, José Ricardo. Direitos humanos e justiciabilidade: pesquisa no Tribunal de Justiça do Rio de Janeiro. Sur. Revista internacional de direitos humanos, v. 2, n. 3, p. 138-172, dez. 2005. Disponível em: <http://www.scielo.br/scielo.php?script=sci_arttext\&pid=S180664452005000200009\&lng=pt\& nrm=iso>. Acesso em: 06 jun. 2018. Há uma versão do artigo em: CUNHA, José Ricardo. Direitos humanos globais e poder judiciário: uma análise empírica sobre o conhecimento e aplicação das normas dos sistemas ONU e OEA no tribunal de justiça do Rio de Janeiro. Novos Estudos Jurídicos. v. 13, n. 2, p. 133-176, jul-dez, 2008.

91 Não se deve, no entanto, olvidar que nesse período a jurisprudência do STF sobre os tratados internacionais de direitos humanos não é a mesma de agora, o que pode influenciar em futuras pesquisas para a busca desses obstáculos na efetividade de direitos.

92 É interessante destacar que os autores se depararam com certa resistência dos magistrados no momento de responder os questionários. Cerca de $40 \%$ das varas se abstiveram de fazê-lo, alegando principalmente três motivos: (i) a recusa não justificada do juiz; (ii) a recusa do juiz devido ao entendimento de que os direitos humanos não faziam parte de seu trabalho; (iii) não recebimento do pesquisador pelo juiz. 
Já sobre algum tipo de vivência pessoal que pudesse fornecer uma experiência prática em relação aos direitos humanos, foi constatado que somente $6 \%$ dos magistrados revelaram já ter tido algum tipo de engajamento nessa área. Por outro lado, sobre a concepção dos juízes sobre os direitos humanos, ao serem questionados sobre a natureza dos direitos humanos, 7,6\% afirmaram serem "valores sem aplicabilidade efetiva"; para 34,3\%, os direitos humanos constituiriam "princípios aplicados na falta de regra específica"; e para 54,3\%, seriam "regras plenamente aplicáveis". Isso reflete ou dá indícios de que os esforços para o reconhecimento e para a consolidação dos direitos humanos ainda eram insuficientes em 2005.

Também foi verificado se os juízes reconheciam a presença de normas de direitos humanos nos casos em que atuavam, a partir de uma noção de que estes direitos possuem uma proteção multinível. Nesse sentido, 24\% dos magistrados responderam negativamente; outros 24\% disseram haver atuado em vários feitos com aplicabilidade de normas dessa natureza; outros 30\% informaram ter atuado em alguns processos em que normas de direitos humanos eram aplicáveis; e outros 24\% afirmaram ter atuado em poucos casos. Se for considerar que o julgador deve ter uma visão sistêmica de todo o Direito, torna-se difícil assumir que há casos em que os direitos humanos não incidam, o que faz com que os autores se perguntem sobre o conhecimento dos magistrados sobre os direitos humanos, uma vez que, "em razão de sua pouca intimidade com o conceito geral e com as normas de direitos humanos, os entrevistados teriam velada sua percepção e isso dificultaria o reconhecimento dos casos afeitos à matéria em menção." ${ }^{93}$

Especificamente sobre se os juízes possuem conhecimento a respeito do funcionamento dos Sistemas Internacionais de Proteção dos direitos humanos, 59\% alegaram ter um conhecimento superficial; e 20\% não sabem como funcionam os Sistemas de Proteção, o que pode, eventualmente, fornecer uma direção na busca das razões para que a já mencionada falta de diálogo entre as cortes internacionais e nacionais permaneça, constituindo-se em uma barreira para a efetivação dos direitos humanos. Por outro lado, sobre o conhecimento das decisões das cortes internacionais de proteção dos direitos humanos, $56 \%$ dos juízes responderam que eventualmente possuem tais informações; $21 \%$ afirmaram que raramente têm; e 10\% nunca obtiveram informações sobre elas; e apenas 13\% disseram que frequentemente têm alguma informação. Já quando foram questionados sobre a possibilidade de o conhecimento dessas decisões colaborar e enriquecer suas sentenças, a resposta de $50 \%$ dos juízes entrevistados foi que sim; $41 \%$ disseram que talvez; e $9 \%$ responderam não. ${ }^{94}$

93 CUNHA, José Ricardo. Direitos humanos e justiciabilidade: pesquisa no Tribunal de Justiça do Rio de Janeiro. Sur. Revista internacional de direitos humanos, v. 2, n. 3, p. 148, dez. 2005. Disponível em: <http://www.scielo.br/scielo.php?script=sci_arttext\&pid=S1806$64452005000200009 \&$ Ing=pt\& nrm=iso>. Acesso em: 06 jun. 2018.

94 CUNHA, José Ricardo. Direitos humanos e justiciabilidade: pesquisa no Tribunal de Justiça do Rio de Janeiro. Sur. Revista internacional de direitos humanos, v. 2, n. 3, p. 151, dez. 2005. Disponível em: <http://www.scielo.br/scielo.php?script=sci_arttext\&pid=S180664452005000200009\&lng=pt\& nrm=iso>. Acesso em: 06 jun. 2018. 
O estudo é muito mais detalhado do que foi aqui exposto, principalmente se reportando à aplicação de documentos específicos dos direitos humanos pelos magistrados, como o Pacto Civil, Econômico, a Convenção Americana, dentre outros. No entanto, os dados aqui apresentados já mostram alguns indícios de gargalos que devem ser trabalhados para uma maior efetividade dos direitos humanos no Brasil, que não passa somente pela atuação do STF e o seu reconhecimento da importância dos Sistemas Internacionais de proteção a esses direitos, mas é algo mais amplo e estrutural, que também envolve valores a serem inseridos na sociedade e uma mudança de mentalidade. É aqui que a Constituição de 1988 tem um protagonismo relevantíssimo, mas que, nesses 30 anos, também se presenciou um movimento contra essa sua posição.

\section{CONSIDERAÇÕES FINAIS}

Este artigo procurou realizar uma breve avaliação dos 30 anos da Constituição Federal de 1988 diante dos direitos humanos, que também completam 70 anos de internacionalização por meio da Declaração Universal dos Direitos Humanos e da Declaração Americana dos Direitos e Deveres do Homem, aprovadas em 1948. A partir disso, e após uma exposição histórico-cronológica da construção desses direitos, verificou-se como vem sendo tratado o tema da recepção dos tratados internacionais de direitos humanos na ordem constitucional brasileira, tanto desde a perspectiva legislativa quanto da judiciária. Logo, também se buscou aportar outros elementos mais objetivos como forma de examinar os gargalos existentes no diálogo entre as cortes internacionais e nacionais, dados estes que permitem, ao menos, indicar possíveis fatores que influenciam no ainda baixo reconhecimento dos direitos humanos no Brasil, mesmo diante da crescente procura dos sistemas internacionais de proteção pelos cidadãos. Nesse ponto, deve-se consignar que pesquisas futuras devem aprofundar e atualizar os dados aqui apresentados.

O fato é que o Brasil, ao menos é o que parece, vai na contramão de uma tendência muito presente na América Latina, que é o da construção e da consolidação de um lus Constitutionale Commune, diante dos graves problemas em comum e que são fortes violadores de direitos humanos, como a pobreza, a profunda desigualdade social, a violência (muitas vezes institucionalizada), a segregação de minorias e tantos outros. Segundo Rodolfo Arango, a noção de um lus Constitutionale Commune aponta para uma da realidade política e social da América Latina, com o objetivo de criar as condições sociais e políticas necessárias para a consolidação da democracia, do estado de direito e dos direitos humanos. ${ }^{95}$

95 ARANGO, Rodolfo. Fundamentos del lus Constitutionale Commune en América Latina: derechos fundamentales, democracia y justicia constitucional. In: BOGDANDY, Armin von; FIX-FIERRO, Hector; MORALES ANTONIAZZI, Mariela. (Coord.). lus Constitutionale Commune en América Latina. Rasgos, potencialidades y desafíos. México: Unam, 2014. p. 25 e ss. 
Nesse sentido, o conceito de um lus Constitutionale Commune na América Latina se refere tanto ao direito positivo quanto ao seu discurso jurídico sobre ele. Trata-se da construção de um direito comum que se justifica por dois aspectos, sendo o primeiro pela abertura dos sistemas jurídicos estatais latino-americanos para um denominador comum em direito internacional público, sobretudo em relação à Convenção Americana (uma relação de mútuo fortalecimento por meio do "bloco de constitucionalidade"), e o segundo por um discurso comum de direito comparado, com estudo, pesquisa, desenvolvimento de uma verdadeira doutrina voltada a essa conjunção entre o Direito Constitucional e os direitos humanos. ${ }^{96}$

Evidencia-se, assim, a inclusão do Brasil no rol de países que já adotam cláusulas de abertura em suas constituições, que há toda uma doutrina desenvolvida em torno de um maior diálogo entre o direito internacional e o interno referente aos direitos humanos, mas que, a despeito disso, suas instituições ainda resistem a essa transformação, muito mais visível nos países vizinhos do que aqui.

Se o que se visa para o futuro é a uma maior concretização dos direitos humanos para a solução dos complexos problemas que alcançam o Brasil - e todos os países latino-americanos -, impõe-se a formação de uma nova cultura jurídica a partir da dignidade da pessoa humana; o fortalecimento dos sistemas internacionais de proteção dos direitos humanos com o apoio da sociedade civil e o avanço na afirmação da democracia e do Estado de Direito. ${ }^{97}$ Para tanto, é indispensável que o Poder Judiciário tenha um maior engajamento na realização desse diálogo multinível, não se limitando aqui a uma revisão da posição jurisprudencial do STF sobre o tema, mas por outros canais vitais, como ações diretas sobre os magistrados para a aplicação desse conjunto de direitos. Isso, logicamente, passa por outras instituições que se envolvem com a formação jurídica de futuros juristas, com a opção por integrar cada vez mais os conhecimentos técnicos em Direitos Humanos nos concursos públicos para distintas carreiras jurídicas e, principalmente, no empoderamento cidadão sobre a utilização dos sistemas de proteção dos direitos humanos.

Nessa linha, opta-se por um Direito Constitucional Humanitário, que não deve estar somente escrito, mas também materializado, porque as constituições são feitas para as pessoas, ou melhor, para nós, "aqui y ahora, en la exígua temporalidade de la vida biográfica de cada hombre que forma parte de nuestra sociedade". ${ }^{98}$

\footnotetext{
96 BOGDANDY, Armin von. Ius Constitutionale Commune na América Latina. Uma reflexão sobre um constitucionalismo transformador. RDA Revista de Direito Administrativo, Rio de Janeiro, v. 269, p. mai./ago. 2015. p. 21-22.

97 PIOVESAN, Flávia. Ius constitutionale commune latino-americano em Direitos Humanos e o Sistema Interamericano: perspectivas e desafios. Revista Direito e Práxis. Rio de Janeiro, v. 8, n. 2, jun. 2017. Disponível em: <http://www.scielo.br/scielo.php?script=sci_arttext\&pid=S2179$89662017000201356 \&$ Ing=pt\&nrm=iso>. Acesso em: 27 jun. 2018. p. 1378 e ss. BIDART CAMPOS, Germán J. El derecho constitucional humanitario. Buenos Aires: Ediar, 1996. p. 21.
} 
Se é assim, deve-se reconhecer que a constituição escrita tem uma textura aberta e que não se fecha nem se esgota em seu texto. A explicação de um sistema de direitos não pode mais se limitar às fronteiras do direito interno. A completude de um sistema de direitos em um Estado democrático requer que este sistema se abasteça também do direito internacional. ${ }^{99}$ Só dessa forma haverá uma retroalimentação na busca de uma solução mais benéfica para os seres humanos, tal como se preconiza desde os direitos humanos. ${ }^{100}$

É dessa maneira que se deseja que sejam os próximos 30 anos da Constituição de 1988, bem como os próximos 70 da Declaração Universal dos Direitos Humanos e da Declaração Americana dos Direitos e Deveres do Homem.

\section{REFERÊNCIAS}

ARANGO, Rodolfo. Fundamentos del lus Constitutionale Commune en América Latina: derechos fundamentales, democracia y justicia constitucional. In: BOGDANDY, Armin von; FIX-FIERRO, Hector; MORALES ANTONIAZZI, Mariela. (Coord.). Ius Constitutionale Commune en América Latina. Rasgos, potencialidades y desafíos. México: Unam, 2014. p. 25-36.

ATIQUE, Henry; NEME, Eliane Franco. O processo de internacionalização como instrumento de efetivação dos direitos humanos: o sistema europeu e o sistema americano. Novos Estudos Jurídicos. v. 13, n. 1, p. 95-106, jan./jun. 2008.

AVELAR, Daniel; PRONER, Carol. A natureza jurídica dos tratados internacionais de direitos humanos e sua harmonização e aplicabilidade no ordenamento jurídico brasileiro. Revista de Direitos Fundamentais e Democracia, Curitiba, v. 10, n. 10, p. 38-87, jul./dez. 2011.

BIDART CAMPOS, Germán J. El derecho constitucional humanitario. Buenos Aires: Ediar, 1996.

BRASIL, Supremo Tribunal Federal. Extradição 1085. Requerente: Governo da Itália. Extraditado: Cesare Battisti. Relator Min. Cezar Peluso. Brasília, 16 de dezembro de 2009. Disponível em: <http://stf.jus.br/portal/jurisprudencia/listarJurisprudencia. asp?s1=\%28CESARE+BATTISTI\%29\&base=baseAcordaos\&url=http://tinyurl.com/y3mdoeyo >. Acesso em: 08 out. 2019.

BRASIL, Supremo Tribunal Federal. Recurso Extraordinário n 580252. Recorrente: Anderson Nunes da Silva. Recorrido: Estado de Mato Grosso do Sul. Relator Min. Alexandre de Moraes. Brasília, 16 de fevereiro de 2017. Disponível em: <http://portal.stf.jus.br/processos/detalhe.asp?incidente=2600961 >. Acesso em: 08 out. 2019.

BRASIL. Supremo Tribunal Federal. Ação Direta de Inconstitucionalidade n 1055. Requerente: Confederação Nacional da Indústria. Requerido: Presidente da República. Brasília, 15 de dezembro de 2016. Disponível em: <http://portal.stf.jus.br/ processos/detalhe.asp?incidente $=1584564>$. Acesso em: 08 out. 2019.

BRASIL. Supremo Tribunal Federal. Habeas Corpus 124.306. Paciente: Edilson dos Santos y Rosemere Aparecida Ferreira. Coator: Superior Tribunal de Justiça. Relator Min. Marco Aurélio. Brasília, 29 de novembro de 2016. Disponível em: http:// portal.stf.jus.br/processos/detalhe.asp?incidente=4637878. Acesso em: 08 out. 2019.

BRASIL. Supremo Tribunal Federal. Arguição de descumprimento de preceito fundamental $n^{\circ} 347$. Requerente: Partido Socialismo e Liberdade - PSOL. Requerido: União Federal. Relator Min. Marco Aurélio. Brasília, 09 de setembro de 2015. Disponível em: http://portal.stf.jus.br/processos/detalhe.asp?incidente=4783560. Acesso em: 08 out. 2019.

99 MORAIS, José Luis Bolzan de; HOFFMAN, Fernando. Por uma identidade constitucional "comum". Revista Novos Estudos Jurídicos Eletrônica, v. 20 - n. 3, p. 860-884, set./dez., 2015.

100 BIDART CAMPOS, Germán J. El derecho constitucional humanitario. Buenos Aires: Ediar, 1996. p.131 e ss. 
BRASIL. Supremo Tribunal Federal. Recurso Extraordinário n 592.581. Recorrente: Ministério Público do Estado do Rio Grande do Sul. Recorrido: Estado do Rio Grande do Sul. Relator Min. Ricardo Lewandowski. Brasília, 13 de agosto de 2015. Disponível em: http://portal.stf.jus.br/processos/detalhe.asp?incidente=2637302. Acesso em: 08 out. 2019.

BRASIL. Supremo Tribunal Federal. Ação Direta de Inconstitucionalidade $n^{\circ} 4815$. Requerente: Associação Nacional dos Editores de Livros - ANEL. Requerido: Presidente da República. Relatora Min. Carmen Lúcia. Brasília, 10 de junho de 2015. Disponivel em: <http://portal.stf.jus.br/processos/detalhe.asp?incidente=4271057>. Acesso em: 08 out. 2019.

BRASIL. Supremo Tribunal Federal. Habeas Corpus n 115.539. Paciente: Eliton Alves Alfaia. Coator: Superior Tribunal de Justiça. Relator Min. Luiz Fux. Brasília, 03 de setembro de 2013. Disponível em: http://portal.stf.jus.br/processos/detalhe. asp? incidente $=4318900$. Acesso em: 08 out. 2019.

BRASIL. Supremo Tribunal Federal. Habeas Corpus n 110.185. Paciente: Ademilson Moreira de Almeida. Coator: Superior Tribunal Militar. Relator Min. Celso de Mello. Brasília, 14 de maio de 2013. Disponível em: http://portal.stf.jus.br/processos/ detalhe.asp?incidente=4134368. Acesso em: 08 out. 2019.

BRASIL. Supremo Tribunal Federal. Recurso Extraordinário n 511.961. Recorrente: Sindicato das Empresas de Rádio e Televisão no Estado de São Paulo - SERTESP. Recorrido: União Federal. Relator Min. Gilmar Mendes. Brasília, 17 de junho de 2009. Disponível em: http://portal.stf.jus.br/processos/detalhe.asp?incidente=2469175. Acesso em: 08 out. 2019.

BRASIL. Supremo Tribunal Federal. Arguição de Descumprimento de Preceito Fundamental $n^{\circ} 153$. Requerente: Conselho Federal da Ordem dos Advogados Do Brasil - OAB. Requerido: Presidente da República. Relator Min. Luiz Fux. Brasília, 29 de abril de 2010. Disponível em: http://portal.stf.jus.br/processos/detalhe.asp? incidente=2644116. Acesso em: 08 out. 2019.

BRASIL. Tribunal de Justiça do Estado do Paraná. Apelação nº 0001795-80.2011.8.16.0019. Apelante: Marcelo Pinheiro. Apelado: Ministério Público do Estado do Paraná. Relator:Des. Luís Carlos Xavier. Curitiba, 30 de setembro de 2019. Disponível em: https://portal.tjpr.jus.br/jurisprudencia/j/4100000010167841/Ac\%C3\% B3rd\%C3\%A3o-0001795-80.2011.8.16.0019\#. Acesso em: 08 out. 2019.

BRASIL. Tribunal de Justiça do Estado do Paraná. Conflito de competência n 1321279-2. Relator: Des. Telmo Cherem. Curitiba, 20 de maio de 2015. Disponível em: https://portal.tjpr.jus.br/jurisprudencia/j/11908502/Decis\%C3\%A3o\%20 monocr\%C3\%A1tica-1321279-2. Acesso em: 08 out. 2019.

BRASIL. Tribunal de Justiça do Estado do Paraná. Habeas Corpus n 0044543-77.2017.8.16.0000. Paciente: Adam Felix Souza dos Santos. Coator: Juízo Criminal de Tibagi. Relator: Des. Maria José de Toledo Marcondes Teixeira. Curitiba, 25 de janeiro de 2018. Disponível em: <https://portal.tjpr.jus.br/jurisprudencia/j/4100000005206951 /Ac\%C3\%B3rd\%C3\%A3o0044543-77.2017.8.16.0000\#integra_4100000005206951> Acesso em: 08 out. 2019.

BRASIL. Tribunal de Justiça do Estado do Paraná. Apelação Cível n 965944-3. Apelante: José Adalberto Maschio. Apelado: Estado do Paraná. Relator Des. Dimas Ortêncio de Melo. Curitiba, 12 de março de 2013. Disponível em: https://portal.tjpr. jus.br/jurisprudencia/j/11424634/Ac\%C3\%B3rd\%C3\%A3o-965944-3. Acesso em: 08 out. 2019.

BOGDANDY, Armin von. lus Constitutionale Commun na América Latina. Uma reflexão sobre um constitucionalismo transformador. RDA - Revista de Direito Administrativo, Rio de Janeiro, v. 269, p. 13-66, mai./ago. 2015.

BONAVIDES, Paulo. Curso de Direito Constitucional. 26. ed. São Paulo: Malheiros, 2010.

CALDEIRA, Teresa Pires do Rio. Direitos Humanos ou "Privilégios de Bandidos"? Desventuras da Democratização Brasileira. Novos Estudos CEBRAP - SP, nº. 30, p. 162-174. julho/91. Disponível em: http://novosestudos.org.br/v1/files/uploads/ contents /64/20080624_direitos_humanos_ou_privilegios_de_bandidos.pdf. Acesso em: 10 jun. 2018.

CALETTI, Leandro; STAFFEN, Marcio Ricardo. O controle de convencionalidade pela via difusa como forma de otimização e exigibilidade dos direitos humanos. Revista da AGU, Brasília-DF, v. 14, n. 04, p. 133-156, out./dez. 2015.

CALETTI, Leandro. O controle difuso da convencionalidade e os direitos humanos no Brasil. Revista IIDH, n. 64, p. 189214, jul./dic., 2016. 
CANOTILHO, José Joaquim Gomes. Direito Constitucional. 6. ed. rev. Coimbra: Almedina, 1993.

CANTOR, Ernesto Rey. Controles de convencionalidad de las leyes. Biblioteca Jurídica del Instituto de Investigaciones Jurídicas de la UNAM. 2011. p. 225-262. Disponível em: <https://archivos.juridicas.unam.mx/www/bjv/libros/6/2562/16. pdf> Acesso em: 22 jun. 2018.

CARVALHO, Feliciano de. Teoria do bloco de constitucionalidade. Anais do XXIII Congresso Nacional do CONPEDI/ UFPB. Florianópolis, 2015, p. 418-444.

. A natureza jurídica constitucional de todos os tratados internacionais de direitos humanos: análise da supralegalidade e da inconsciência do Supremo Tribunal Federal brasileiro. Anais do XXII encontro nacional do CONPEDI, 2013, p. 137-157.

CHUEIRI, Vera Karam de. Fundamentos do Direito Constitucional. Curitiba: IESDE, 2009.

COMPARATO, Fábio Konder. A afirmação histórica dos Direitos Humanos. 10. ed. São Paulo: Saraiva, 2016.

COMTE, Augusto. Discurso sobre o espírito positivo. [s.d.]. Disponível em: <http://www.ebooksbrasil.org/adobeebook/ comte.pdf>. Acesso em: 22 jun. 2018.

CONSTANT, Benjamin. The liberty of ancients compared with that of moderns. Disponível em: http://lf-oll. s3.amazonaws.com/titles/2251/Constant_Liberty1521_EBk_v6.0.pdf. Acesso em: 14 jun. 2018.

CUNHA, José Ricardo. Direitos humanos e justiciabilidade: pesquisa no Tribunal de Justiça do Rio de Janeiro. Sur. Revista internacional de direitos humanos, v. 2, n. 3, p. 138-172, dez. 2005. Disponível em: <http://www.scielo.br/scielo. php?script=sci _arttext\&pid=S1806-64452005000200009\&lng=pt\&nrm=iso >. Acesso em: 06 jun. 2018.

CUNHA, José Ricardo. Direitos humanos globais e poder judiciário: uma análise empírica sobre o conhecimento e aplicação das normas dos sistemas ONU e OEA no tribunal de justiça do Rio de Janeiro. Novos Estudos Jurídicos. v. 13, n. 2, p. 133-176, jul-dez, 2008.

FACHIN, Luiz Edson. Notas para um ensaio sobre a posição jurídica dos tratados internacionais de direitos humanos no Brasil após a reforma constitucional. In: PRONER, Carol; CORREAS, Óscar (Coord.). Teoria crítica dos direitos humanos. Belo Horizonte: Fórum, 2011. p. 153-163.

GABARDO, Emerson. Interesse público e subsidiariedade: o Estado e a sociedade civil para além do bem e do mal. Belo Horizonte: Fórum, 2009.

GUERRA, Sidney. Controle de convencionalidade. Revista Jurídica. vol. 01, n. 46, Curitiba, p. 1-21, 2017.

HÄBERLE, Peter. El Estado constitucional. México: UNAM, 2001.

Hermenêutica constitucional: a sociedade aberta de intérpretes da Constituição: contribuição para a interpretação pluralista e procedimental da Constituição. Tradução de Gilmar Ferreira Mendes. Porto Alegre: Sergio Antônio Fabris Editor, 1997.

HESPANHA, Antônio Manuel. Cultura jurídica europeia - Síntese de um milênio. Coimbra: Almedina, 2012.

JELLINEK, Georg. System der Subjektiven Öffentlichen Rechte. Freiburg: Mohr, 1892.

KELSEN, Hans. Teoria pura do Direito. 6. ed. Rio de Janeiro: Martins Fontes, 1998.

LOPES, Dalliana Vilar; LOPES, Gills Vilar. A internalização dos tratados sobre Direitos Humanos na ordem jurídica brasileira e a problemática da ordem internacional. Universitas Relações Internacionais, Brasília, v. 14, n. 1, p. 51-59, jan./jun. 2016.

LORA ALARCÓN, Pietro de Jesús. Constituição e Direito Intergentium: a ductibilidade pro homine e o possível ius commune para os desafios jurídicos contemporâneos. In: PAGLIARINI, Alexandre Coutinho; DIMOULIS, Dimitri (Coord.). Direito constitucional e internacional dos direitos humanos. Belo Horizonte: Fórum, 2012. p. 49-72. 
MAUÉS, Antônio Moreira. Supralegalidade dos tratados internacionais de direitos humanos e interpretação constitucional. In: SOARES, Mário Lúcio Quintão; SOUZA, Mércia Cardoso de (Coord.). A interface dos direitos humanos com o direito internacional. Tomo I, Belo Horizonte: Fórum, 2015. p. 137-162.

MAZZUOLI, Valério de Oliveira. O controle jurisdicional da convencionalidade das leis no Brasil. In: SOUSA, Marcelo Rebelo et al. (Coords.). Estudos em homenagem ao Prof. Doutor Jorge Miranda, v. III (Direito constitucional e justiça constitucional). Coimbra: Coimbra Editora, 2012, p. 759-776.

Podem os tratados de direitos humanos não "equivalentes" às emendas constitucionais servir de paradigma ao controle concentrado de convencionalidade? RDU. v. 12, n 64, p. 222-229, jul./ago., 2015.

MESSA, Ana Flávia; FRANCISCO, José Carlos. Tratados internacionais sobre direitos humanos e poder constituinte. In: PAGLIARINI, Alexandre Coutinho; DIMOULIS, Dimitri (Coord.). Direito constitucional e internacional dos direitos humanos. Belo Horizonte: Fórum, 2012. p. 241-276.

MEYER-PFLUG, Samantha Ribeiro. A internacionalização do Direito Constitucional brasileiro. In: PAGLIARINI, Alexandre Coutinho; DIMOULIS, Dimitri (Coord.). Direito constitucional e internacional dos direitos humanos. Belo Horizonte: Fórum, 2012. p. 277-292.

MIRANDA, Jorge. Manual de Direito Constitucional. Tomo IV. 4. ed. rev. atual. Coimbra: Coimbra Editora, 2008.

MORAIS, José Luis Bolzan de; HOFFMAN, Fernando. Por uma identidade constitucional "comum". Revista Novos Estudos Jurídicos - Eletrônica, v. 20 - n. 3, p. 860-884, set./dez., 2015.

NEVES, Marcelo. A Força Simbólica dos Direitos Humanos. Revista Brasileira de Direito Público RBDP. Belo Horizonte, n. 3, ano 1 Outubro/Dezembro, 2003. Disponível em: <http://www.bidforum.com.br/bid/PDI0006.aspx?pdiCntd=12542>. Acesso em: 26 jun. 2018.

PEREIRA, Taís Mariana Lima. O cumprimento das decisões da corte interamericana de direitos humanos pelo Brasil. EJJL. Chapecó, v. 14, n. 2, p. 315-348, jul./dez. 2013.

PIOVESAN, Flavia. Brasil e o Sistema Interamericano de Proteção dos Direitos Humanos. In: Temas de Direitos Humanos. 10. ed. São Paulo: Saraiva, 2017. p. 102-147.

lus constitutionale commune latino-americano em Direitos Humanos e o Sistema Interamericano: perspectivas e desafios. Revista Direito e Práxis. Rio de Janeiro, v. 8, n. 2, p. 1356-1388, jun. 2017. Disponível em: <http://www.scielo. br/ scielo.php?script=sci_arttext\&pid=S2179-89662017000201356\&lng=pt\&nrm=iso >. Acesso em: 27 jun. 2018.

Direitos humanos e o direito constitucional internacional. São Paulo: Saraiva, 2006.

RAMOS, André de Carvalho de. Curso de Direitos Humanos. 4. ed., 2017.

RIEDEL, Eibe. Menschenrechte der Dritten. In: Europäische Grundrechte-Zeitung, p. 9-21, 1989.

ROTHEMBURG, Walter Claudius. Controle de constitucionalidade e controle de convencionalidade: o caso brasileiro da lei da anistia. In: PAGLIARINI, Alexandre Coutinho; DIMOULIS, Dimitri (Coord.). Direito constitucional e internacional dos direitos humanos. Belo Horizonte: Fórum, 2012. p. 333-359.

SALGADO, Eneida Desiree. Constituição e democracia - tijolo por tijolo em um desenho (quase) lógico: vinte anos de construção do projeto democrático brasileiro. Belo Horizonte: Fórum, 2007.

SANTIAGO, Nestor Araruna; MARTINS, Eduardo Almendra. O garantismo e os precedentes da Corte Interamericana de Direitos Humanos: efeito vinculante aos Estados sob sua jurisdição. Revista Novos Estudos Jurídicos - Eletrônica, Vol. 21 - n. 2, p. 569-601, mai-ago, 2016.

SARLET, Ingo Wolfgang. Considerações a respeito das relações entre a Constituição Federal de 1988 e os tratados internacionais de direitos humanos. Revista TST. v. 77, n 4, p. 162-185, out./dez., 2011. 
Novos Estudos Jurídicos

Algumas normas sobre a incorporação e a hierarquia dos tratados internacionais em matéria de Direitos Humanos na ordem jurídica brasileira, especialmente em face do novo $\S 3^{\circ}$ do art. $5^{\circ}$ da Constituição de 1988 . Revista de Direito Administrativo. v. 245, p. 69-86, 2007.

SARLET, Ingo Wolfgang; MARINONI, Luiz Guilherme; MITIDIERO, Daniel. Curso de Direito Constitucional. São Paulo: Revista dos Tribunais, 2012.

SCHIER, Paulo Ricardo. Hierarquia constitucional dos Tratados Internacionais de Direitos Humanos e Emenda Constitucional 45 - Tese em favor da incidência do tempus regit actum. 2008. Disponível em: http://www.publicadireito. com.br/conpedi/ manaus/arquivos/anais/XIVCongresso/063.pdf. Acesso em: 28 nov. 2017.

SZAZI, Eduardo. A violência estatal perante os sistemas internacionais de Direitos Humanos. Artigo não publicado, 2017.

TRINDADE, Antônio Augusto Cançado. Cançado Trindade Questiona a Tese de "Gerações de Direitos Humanos" de Norberto Bobbio. Disponível em: http://www.dhnet.org.br/direitos/militantes/cancadotrindade/cancado_bob.htm. Acesso em: 14 jun. 2018.

Tratado de direito internacional dos direitos humanos. Porto Alegre: Sérgio Antônio Fabris Editor, 1997. v. 1, p. 434.

VASAK, Karel. A 30-Year struggle: the sustained efforts to give force of law to the Universal Declaration of Human Rights. The Unesco Courier. Paris: Unesco, 1977. p. 29-32. Disponível em: http://unesdoc.unesco.org/images/0007/000748/074816eo. pdf\# nameddest=48063. Acesso em: 14 nov. 2017.

VELLOSO, Carlos Mario da Silva. Os tratados na jurisprudência do Supremo Tribunal Federal. Revista de informação legislativa, v. 41, n. 162, p. 35-45, abr./jun. 2004.

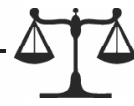

RECEBIDO EM: 16/08/2019

APROVADO EM: 23/10/2019 